\title{
Impacts of land use conflicts on riverine ecosystems
}

\author{
Renato F. Valle Junior ${ }^{1,2,3}$, Simone G.P. Varandas ${ }^{2,3}$, Fernando A.L. \\ Pacheco $^{2,4, *}$, Vítor R. Pereira ${ }^{3}$, Cátia F. Santos ${ }^{2}$, Rui M.V. Cortes ${ }^{2,3}$, Luís F. \\ Sanches Fernandes ${ }^{2,3}$
}

1: IFTM - Instituto Federal do Triangulo Mineiro, Campus Uberaba, Uberaba MG, Brazil

2: UTAD - University of Trás-os-Montes e Alto Douro, Quinta de Prados, 5001-801 Vila Real, Portugal

3: CITAB-UTAD - Centre for Research and Technology of Agro-Environment and Biological Sciences, University of Trás-os-Montes e Alto Douro, Quinta de Prados, 5001-801 Vila Real, Portugal

4: DG-CQVR-UTAD - Department of Geology and Chemistry Research Centre, University of Trás-os-Montes e Alto Douro, Quinta de Prados, 5001-801 Vila Real, Portugal

*Corresponding author; e-mail fpacheco@utad.pt, URL: www.utad.pt, telephone: +351259350 280, fax: +351259350480 


\section{ABSTRACT}

Starting from a diagnosis of areas with different environmental land use conflicts located in various rural sub-basins of the River Sordo basin (northern Portugal), the present study analysed the ecological quality of surface water in small mountain streams to establish a relationship between land use, water and aquatic biota. Environmental land use conflicts were set up on the basis of land use and land capability maps, coded as follows: 1-agriculture, 2-pasture, 3-pasture/forest, and 4-forest. Land capability was assessed by the ruggedness number methodology $(R N)$. The difference between the codes of capability and use defines a conflict class, where a negative or null value means no conflict and a positive value means class $i$ conflict. Within and without the conflict areas, ecological quality of surface water was evaluated by the metrics EPT taxa, $\operatorname{IPtI}_{\mathrm{N}}$ index, diversity of Shannon-Wiener and Evenness index. Macroinvertebrate communities are strongly correlated to conflict classes, because sites without (reference sites) or with minor physicochemical and hydromorphological degradation (Class 1) presented high diversity, evenness, EPT taxa and $\mathrm{IPtI}_{\mathrm{N}}$ index, while more impacted sites (Class 2) presented an ecological status not fulfilling the demands of the European Union Water Framework Directive (2000/60). The present study indicates a significant impact of land use on water quality which has straight influence on the distribution of biota, emphasizing the key role of riparian vegetation in the conservation of aquatic ecosystems. The highest impacts on macroinvertebrate assemblages were associated with changes in water quality parameters such as temperature, oxygen saturation (\%), turbidity, total suspended solids (TSS), nitrates, phosphates and sulphates, conductivity and dissolved oxygen, as well as hydromorphological alterations driven by the total absence of riparian vegetation as a consequence of terrace building, agriculture and the resectioning/reinforcement of the banks associated with the culture of vine. 
Macroinvertebrates proved reliable to distinguish conflict classes and separate seasons.

The main conservation measures required to improve the conflict areas in the short and medium term mainly include the adoption of agroforestry practices as these not only improve the quality of water and soil, maintaining land resources over a long period of use, but also brings many benefits to the landowner.

Keywords: land capability, water quality, environmental degradation, macroinvertebrates. 


\section{INTRODUCTION}

The use and occupation of land with disregard for the soil characteristics, together with the lack of conservation strategies, has led to a quick rise in erosion worldwide. The increase in soil erosion reduces cropland productivity and amplifies the pollution levels of surface water bodies (rivers and lakes). In the sequel, wildlife habitats may suffer a loss above their tolerance limits, compromising the sustainability of ecosystems and the social-economic development (Lal and Stewart, 1990; ISRIC/UNEP, 1991; Pimentel, 1993; Pimentel et al., 1995; Pimentel and Kounang, 1998; Valle Junior et al., 2010). In the present study the focus is put on the potential impacts of land use conflicts on riverine ecosystems. According to Agroconsultores and Coba (1991), in traditional Portuguese agrarian systems land uses comply with the land capability set up on the basis of soil features (depth, fertility) and local environmental conditions (topographic slope, water availability). However, in some rural areas the current land use deviates from those established by land capabilities generating different land use conflicts with consequences on soil erosion intensity (Mello Filho, 1992; Pacheco et al., 2014) and groundwater quality (Valle Junior et al., 2014b). The accelerated soil losses result from a human misuse of the land and are no longer being compensated by the geologic substrata or by the alluvial contributions (Pimentel, 2006). The same author highlights that soil is being lost at rates 10 to 40 times faster than the rate of soil renewal, endangering future human food security and environmental quality. The degradation of groundwater quality is related to amplified washouts of nutrients (e.g. nitrate) in the conflict areas, relative to the washouts in no conflict areas. Governments and international organizations are familiar with these threats, the reason why sustainable development has been a topic on their political agenda over the last four decades (e.g. Stockholm Declaration, 1972; World Conservation Strategy - IUCN, 1980; World 
Commission on Environment and Development- WCED, 1987, known as the Brundtland Report; United Nations Conference on Environment and Development UNCED, 1992). Invariably, the proposed solutions to the problem were strongly focused on the rational use of soils and prevention of water pollution, as these resources are essential for human life and concomitantly are scarce and vulnerable (Pearce et. al., 1989; Murcott, 1997; De Wit and Verheye, 2009).

In Mediterranean countries, forest fires are probably the most important cause of desertification and surface water quality degradation (Moreno et al., 1998; Vallejo, 1997; Rubio, 1987). In Portugal, the burned area increased significantly since the 80s, and now represents more than one third of mainland Portugal (Nunes, 2012). Some intensive agricultural practices - together the effects of forest fires - contributes to the destabilizing of agrarian ecosystems, with consequences on riverine ecosystems located downwards (Roose, 1994). Other common circumstances leading to desertification and concomitant surface water quality degradation comprise the inadequate management of forest spots or the destruction of vegetation cover for the expansion of agricultural areas (Valle Junior et al., 2014a). Regardless the cause, the distinctive climate and strong relief of Mediterranean region enhanced soil erosion and surface water pollution to levels that are more catastrophic than those observed in other regions around the world. According to Corine Land Cover (2007), a large proportion of continental Portugal (43\%) is at high risk of soil erosion, being covered by arid, acidic, sandy, and sometimes rocky soils (Portugal, 2014). In this study, land use conflicts, not compensated by proper soil conservation practices, are an additional degradation source of surface water.

The impacts of multiple land uses on water quality have been studied (Hascic and $\mathrm{Wu}$, 2006; Langpap et al., 2008) and showed that the intensive land use activities may affect 
the hydrological, biological, chemical and geomorphological aspects of aquatic systems (Gergel et al., 2002; Roy et al., 2003; Thompson and Towsend, 2004; Valle Junior, 2008). Many other studies have illustrated the correlation between land use types and water quality parameters (Sliva and Williams, 2001; Oliveira and Cortes, 2005; Schoonover, et al., 2005; Stutter et al., 2007). In one study by Tu (2011), the relationship was even set up by geographically weighted regression so the spatial variation in watershed characteristics and pollution sources could be properly accounted for. Understanding the influence of land use on the concentration of surface water nutrients is particularly useful when considering diffuse pollution, namely agriculture, because this knowledge is crucial for the setting up of best management practices (Mouri et al., 2011). Even more useful is the eventual capture of these practices into land use and(or) aquatic resources policies, as well as their social-economic benefits. On a broader perspective, understanding the specific interactions between land use and surface water quality enables better predictions of future impacts of land use change driven by climate change (Abler et al., 2002). Also Fidelis and Roebeling (2014) discuss the importance of a strong linkage between land use and water ecosystems to enhance the success of the Water Framework Directive (WFD, Directive 2000/60/EC of the European Parliament and of the Council of 23 October 2000). The WFD establishes a framework for Community action in the field of water policy and is said to have a strong territorial context as it establishes its implementation through river basin management plans based on natural water resources systems and associated boundaries, instead of on administrative boundaries (EEA, 2012).

Several indicators have been used to evaluate human actions within river watersheds (Turner, 1990; Li and Wu, 2004; Cortes et al., 2002; Oliveira and Cortes, 2005; Cortes et al., 2013). Among these indicators one may refer biological quality elements such as 
the macroinvertebrates. The advantage of using these proxies has been documented (Hellawell, 1986; Rosenberg and Resh, 1993; Southerland and Stribling, 1995; Hauer and Resh, 1996) and associated to the limited migration patterns, a sessile mode of life, and the sensitivity to numerous environmental factors, of macroinvertebrates (Oliveira and Cortes, 2005; Fernández-Díaz et al., 2008; Pérez-Bilbao and Garrido, 2009; Benetti and Garrido, 2010). As reported in Mandaville (1979) and Lucadamo et al. (2007), the use of biotic indices based on macroinvertebrates are about five times more frequent than the use of any other indicator, and the frequency keeps growing. Worldwide, biomonitoring programs have been developed to detect ecosystem degradation, prioritize conservation areas and evaluate restoration progress.

Notwithstanding the impacts of land use on the quality of surface water have been assessed by a considerable number of researches, only a few studies attempted to make a diagnosis on the ecological status of river ecosystems in areas where environmental land use conflicts exist (Valle Junior, 2008; Valle Junior et al., 2013). The main purposes of this paper are: 1) to identify areas of land use conflict in a small river basin of northern Portugal (River Sordo basin), following the method proposed by Mello Filho and Rocha (1992), Pissarra et al. (2004) and Valle Junior (2008). This method requires the prior assessment of land capability. In this study, land capability was assessed by the ruggedness number $(R N)$ approach (Strahler, 1952). The $R N$ is the product of basin relief (combination of hillside slope with its length) and drainage density. The $R N$ is viewed by Slaymaker (2010) as a potential indicator for the hazardousness of a basin, mainly when related to runoff and sediment mobilization, erosion on hillsides and fluvial erosion; 2) to investigate the ecological status of River Sordo surface waters within and without the conflict areas, based on physicochemical parameters and benthic macroinvertebrates. The seasonal variation of macroinvertebrate 
distribution and of physicochemical variables are addressed as secondary purposes; 3 ) to propose measures for soil conservation and surface water protection, which should be implemented in the near future within conflict areas; 4) to provide the first outcome of a model designed for the expeditious screening of land use conflicts and their consequences on surface water quality, which requires limited amount of data and is easily transportable from one region to another.

\section{MATERIALS AND METHODS}

\subsection{Study area}

The River Sordo basin, which is integrated in the large River Douro basin, is located in the region of Trás-os-Montes, NE Portugal. With an area of approximately $51.2 \mathrm{~km}^{2}$, the basin is located between the northern latitudes of $41^{\circ} 16^{\prime} 05.57^{\prime \prime}-41^{\circ} 20^{\prime} 12.81^{\prime \prime}$ and the western longitudes of $7^{\circ} 55^{\prime} 21.82^{\prime \prime}-7^{\circ} 45^{\prime} 42.45^{\prime \prime}$, covering a small portion of the Vila Real district (Fig. 1a). For a decade, this region is being used as experimental site for studies on very diverse hydrologic and environmental topics, such as the modeling rock weathering at the spring site scale (Pacheco and Alencoão, 2006), the assessment of groundwater vulnerability based on a modified DRASTIC model (Pacheco and Sanches Fernandes, 2013), the identification and characterization of groundwater flow systems and bimodal landscapes as well as their coupling with rock weathering models (Pacheco and Van der Weijden, 2014), the management of water resources based on spatial decision support systems (Sanches Fernandes et al., 2011), the prediction of nitrogen concentrations in river water and the concomitant evaluation of consequences to the supply of public water, within the framework of climate change forecasting (Sanches Fernandes et al., 2012), the consideration of land use conflicts as threats to soil conservation (Valle Junior et al., 2014a) or groundwater quality (Valle Junior et al., 
2014b), and the impact analysis of land use conflicts on surface water quality and riverine ecosystems (this study).

The River Sordo basin is shaped on a mountainous area where the altitudes range from 185 to 1300 meters above sea level. Due to the orography and a relatively short distance to the Atlantic coast, the annual precipitation exceeds $1000 \mathrm{~mm} \mathrm{yr}^{-1}$ and the mean annual temperature approaches $14^{\circ} \mathrm{C}$. The main water course in River Sordo basin is approximately $20 \mathrm{~km}$ long and, in combination with its tributaries, forms a tree like (dendritic) drainage network. Slopes are gentle along streams, especially in the central area where the landscape is characterized by an ample valley, being steep in the adjacent hillsides. In the course of geomorphic development, a group of 53 sub-basins were individualized (Fig. 1b). Because of a differential development, sub-basins in the western region, where the basin is wider, reached an order 4 of Strahler (Strahler, 1957). In the eastern region, where the basin shrinks, the sub-basins are mostly of order 1 . The geology is characterized by crystalline rocks covered in the central area by alluvial deposits extending over an area of approximately $3.2 \mathrm{~km}^{2}$ (Sousa, 1982). The most representative soil types are the leptosols, but in association with the main streams, especially in the central area, some spots of fluvisols were also formed. In the eastern limit of the basin, some anthrosols were developed in connection with the expansion of vineyards and olive yards (Fig. 1c). Land use in the areas of gentle relief is characterized by annual crop agriculture or natural pastures, while in the steep hillsides vegetation is mostly characterized by pine, eucalyptus or mixed forests and shrub land. Finally, in a small area of the eastern side of the basin land is occupied by vineyards and olive yards. Usually, the occupation of land by man did not interfere with riparian vegetation developed at the margins of the streams. The exception is the vineyards, where plantations are frequently extended to the edges of the water bodies. Fig. 1d 
illustrates the land uses in 2007. The landscape has changed moderately between 1990 and 2007, mostly because many shrub land areas (representing $47.8 \%$ of the basin in 1990) were converted into forests $(35.1 \%)$, permanent cultures $(2.7 \%)$, pastures $(3.4 \%)$, and urban areas (4.9\%). The conversion of agriculture areas into pasture land reflects the well-known decline of agriculture as a subsistence activity of many families, which followed the adherence of Portugal to the EU and the implementation of a common agriculture policy.

\subsection{Digital database and computational tools}

The digital data concerning the drainage network and topographic contours were acquired to the Military Geographic Institute (http://www.igeoe.pt). The data, at the 1:25 000 scale, covers the sheets no. 101 and no. 114 of the Portuguese Topographic Map, with a vertical equidistance of $10 \mathrm{~m}$ between adjacent topographic contours. The planimetric datum is the Lisbon Hayford Gauss, with the Universal Transverse Mercator (UTM) projection. Based on the topographic contours, a Digital Elevation Model was generated (Fig. 1a), from which a terrain slope map was produced following the Embrapa (1999) classes (Tab. 1) to be used in the conflict analysis. The soil map (Fig. 1c) was based on the Agroconsultores and Coba (1991) cartography, georeferenced in the Lisbon Hayford Gauss coordinate system, UTM projection. The land use map (Fig. 1d), with the same coordinate system, was based on the Corine Land Cover (2007) 1:100 000 scale cartography, produced by the Portuguese Geographic institute (IGP) for continental Portugal, available at http://www.igeo.pt. This map discriminates 44 land use classes with minimum cartographic units of 5 ha. The 44 classes were grouped into six wide-range land uses for inclusion in the land use conflict analysis. All computational modelling of the spatial data was executed by the IDRISI 
Selva software (Eastman, 2012) developed by the Clark Labs researchers working at the Geography Department of the Clark University (http://www.clarklabs.org).

\subsection{Diagnostic criteria of land capability}

The hydrographic sub-basins of River Sordo watershed were characterized for land capability using a morphometric analysis based on parameters such as topographic slope $(S l)$ and drainage density $\left(D_{\mathrm{d}}\right.$; Horton, 1945$)$, coupled as ruggedness number $(R N=S I \times$ $D_{\mathrm{d}}$; Strahler, 1952). The approach used to calculate the $R N$, and hence land capability, is described in great detail in the studies by Valle Junior et al. $(2013,2014 b)$ and Rocha and Kurtz (2001), and will not be reproduced here. In brief, sectors of a watershed with a low $R N$ are assumed capable for the practicing of cropping agriculture as they correspond to undulated low dissected areas. When the $R N$ is high the sectors are found proper for an occupation by forests because they are sloping and considerably dismembered. Finally, sectors of the basin with intermediate $R N$ are adequate for livestock pasturing or for a mosaic of natural pastures and forests. The boundaries of each $R N$ class are set up as follows: (a) the River Sordo basin is subdivided in a number of nested sub basins (Fig. 1b) and the $R N$ of each sub-basin is calculated; (b) the highest $(\max R N)$ and lowest $(\min R N) R N$ among the sub-basins are evaluated and then the $R N$ amplitude $(\max R N-\min R N)$ is calculated and divided by a number of pre-defined land capability classes. In this study this number is four, with the classes being identified by uppercase letters (A, B, C and D) and defined according to Tab. 2; (c) finally, the subbasins are allocated to the classes, based on their individual $R N$ scores, from which a land capability map is prepared. 


\subsection{Analysis of environmental land use conflicts}

The environmental land use conflict is the divergence of an actual use from a natural use determined by land capability. This conflict can be graduated to express the departure between the natural and actual land uses. The steps required to accomplish this goal were thoroughly described in the studies of Valle Junior et al. $(2013,2014 b)$ when these authors were working in areas dominated by agriculture, forestry and livestock production. Firstly, land capabilities and actual uses were ranked in ascending order of their resemblance with agriculture, and given the ranks 1 (agriculture), 2 (livestock production), 3 (mixed livestock production and forestry) and 4 (forestry), as shown in Tab. 2. Secondly, the conflict was equated to the difference between the codes of capability $(1 \leq \mathrm{N} \leq 4)$ and actual land use $(1 \leq \mathrm{A} \leq 4)$. According to this method, $a)$ the no conflict areas are represented by regions where $N-A \leq 0$, with the negative values representing areas with potential for a sustainable expansion of agriculture or livestock pasturing; $b$ ) areas where the value of the difference between capability and actual use is equal to 1 or 2 are classified as Class $1(N-A=1)$ or Class $2(\mathrm{~N}-\mathrm{A}=2)$ conflict areas, respectively; $c)$ areas with potential for forestry $(N=4)$ but occupied with a farm $(A=1)$ are referred to as Class $3(N-A=3)$. According to Valle Junior (2008), the risks and limitations allocated to conflict classes 1 to 3 are: (Class 1) these lands represent a low risk for surface water contamination and riverine ecosystem degradation when used for annual crops or pastures. The attenuation of the risks may be accomplished by the implementation of soil conservation measures resorting to vegetative and(or) mechanical techniques; (Class 2) these lands represent a medium risk for surface water contamination and riverine ecosystem degradation and hence are incapable for the practice of intensive cultivation, although being adapted for livestock pasturing, reforestation or environmental preservation; (Class 3) these lands represent a 
high risk for surface water contamination and riverine ecosystem degradation and therefore are not capable of being used for intensive cropping or livestock pasturing; nonetheless, they are still capable of being reforested or used for environmental preservation.

\subsection{Biological condition in conflict areas}

To characterize the biological quality of surface water using macroinvertebrates, five sites along the River Sordo basin were sampled in no conflict areas as well as in conflict areas of a given class. The sampling was conducted on a monthly basis between March and August 2013. The sampling sites were coded as follows: no conflict (or reference) Ref; Conflict $1-\mathrm{C} 1 \mathrm{a}$ and C1b; Conflict $2-\mathrm{C} 2 \mathrm{a}$ and C2b; and Conflict $3-\mathrm{C} 3$. The lowercase letters ( $a$ and $b$ ) indicate different sites within the same conflict class. Samplings were carried out in wet (spring) and dry (summer) periods in order to evaluate the effect of seasonality (different hydraulic regimes) on macroinvertebrate communities. The sampling dates and periods, as well as the associated climatic data, are depicted in Tab. 3. For the Conflict 3 site (C3), only the water discharging from a very small water gallery was identified. Thus, it was decided not make macroinvertebrate samplings at this site, since the data would not be comparable to the data of other conflict areas.

Samples of macroinvertebrate assemblages were collected with a $500 \mathrm{~mm}$ mesh handnet ( $1 \mathrm{~m}$ long by $0.25 \mathrm{~m}$ wide), using semi-quantitative techniques. Organisms were obtained by kick-sampling during 2 minutes (Catch Per Unit Effort - CPUE) proportionally covering all range of present habitats (inorganic: coarse, sandy, and muddy substrates; organic: algae, aquatic macrophytes, and organic matter-CPOM) in sedimentation and erosion zones, starting from a riffle. Collections were combined and 
organisms were sorted alive in the laboratory. Invertebrates were preserved in $70 \%$ ethanol and identified to the family level. In agreement with Barbour et al. (1999), this taxonomic level of identification provides a higher degree of precision among samples and taxonomists, requires less expertise to perform, and accelerates the assessment to results. Marshall et al. (2006) found that very little information $(<6 \%)$ was lost by identifying taxa to family (or genus), as opposed to species, and that quantifying the abundance of taxa provided greater resolution for pattern interpretation than simply noting their presence/absence.

\subsection{Physicochemical water quality}

The quality of surface water in the River Sordo basin was evaluated at the same time and the same sites used for the macroinvertebrate samplings. The physicochemical parameters were measured using a multi parametric sea gauge YSI 6820 and a portable multi meter Hach HQ40d for measurements in situ: water temperature $\left({ }^{\circ} \mathrm{C}\right), \mathrm{pH}$, dissolved oxygen $\left(\mathrm{mg} \mathrm{O}_{2} \mathrm{~L}^{-1}\right)$ and saturation $(\%)$, specific conductance $\left(\mu \mathrm{S} \mathrm{cm}^{-1}\right)$, and Oxidation Reduction Potential (ORP or Redox Potential - mV). Additionally, water samples were collected, kept in coolers, and transported to the laboratory for analyses of nitrate $\left(\mathrm{mg} \mathrm{NO}_{3}{ }^{-} \mathrm{L}^{-1}\right)$, total phosphate $\left(\mathrm{mg} \mathrm{P} \mathrm{L}^{-1}\right)$, sulphate $\left(\mathrm{mg} \mathrm{SO}_{4}{ }^{2-} \mathrm{L}^{-1}\right)$, alkalinity ( $\mathrm{mg} \mathrm{HCO}_{3}{ }^{-} \mathrm{L}^{-1}$ ), and total suspended solids (TSS $-\mathrm{mg} \mathrm{L}^{-1}$ ), turbidity (NTU), using molecular-absorption spectrometry. Values were classified according to the Decree-Law 236/1998, the alterations made by the Directive 2009/90/EC of the Commission, which laid down technical specifications for chemical analysis and monitoring of water status, and by the Act No. 58/2005 (the Water Act). 


\subsection{Statistical analysis}

\subsubsection{Regional patterns of morphometric parameters}

Evaluation of land capability by the ruggedness number approach requires that morphometric parameters can be described by single unimodal populations. This requisite may not be totally satisfied in areas characterised by a diversity of geologic or soil substrata (present case). In these cases, application of the $R N$ method must be preceded by an investigation of regional morphometric patterns using analyses of variance (One-way repeated measures ANOVA) of terrain slope $(S I)$, drainage density $\left(D_{\mathrm{d}}\right)$ and ruggedness mumber $(R N)$. For the present study, these analyses were executed by the software MINITAB INC. (2003). The goal was to explore the variability on the values of $S l, D_{\mathrm{d}}$ and $R N$ considering the most representative soil types in the basin (leptosols and anthrosols), which were also the soil types present at the sampling sites. Subsequently to ANOVA, a Tukey post hoc test (significance level: $p<0 \cdot 05$ ) was applied to the inspected variables.

\subsubsection{Statistical indices of biological condition}

To characterize and compare the macroinvertebrate communities in each site, we calculated family level richness (S), Shannon-Wiener diversity index $\left(\mathrm{H}^{\prime}\right)$ and species evenness (Pielou's evenness index J'). Also, the macroinvertebrate data set were used to calculate a benthic index of biotic integrity $\left(\mathrm{IPtI}_{\mathrm{N}}-\right.$ North Invertebrate Portuguese Index; INAG, 2009). The final IPtI $_{\mathrm{N}}$ normalized value was expressed as an Ecological Quality Ratio (EQR, numerical value scaled between 0 and 1), where 1 represents (typespecific) reference conditions and values close to 0 indicate bad ecological status. EQR values were classified according to the criteria of the Portuguese Water Institute (INAG, 
2009). This classification comprises five different classes, namely, excellent, good, moderate, poor and bad.

In order to capture major patterns and to detect distinct macroinvertebrates assemblages between sites and seasons, a Non-metric Multidimensional Scaling (NMDS) analysis was used $(\log (x+1)$ transformed, matrix of relative abundances). The different groups observed in this analysis were further used as grouping factor. Then, differences observed among groups were tested using two-way crossed analysis (ANOSIM). This analysis is based on the ratio $(R)$ of the between-group to within-group similarity ranking and ranges from 0 to 1 , with $R$ indicating the degree of dissimilarity $(1=$ completely dissimilar; $0=$ completely similar). Pairwise comparison tests were also calculated which generate an $R$ value and a significance $(p)$ value for each possible pair of comparisons. The importance of the pairwise tests is not so much the significance level, which can be low because of few replicates in each group, but rather the $R$ value which provides an absolute dissimilarity measure among the samples: $\mathrm{R} \geq 0.75$ - well separated; $0.75>R \geq 0.5$ - overlapping but different; $0.5>R \geq 0.25$ - overlapping but somewhat different; $R<0.25$ - insufficiently different (Clarke and Gorley, 2001; Clarke and Warkick, 2001). Also, a SIMPER analysis (an exploratory analysis of similarity) was done to quantify the degree of differences found between types of conflicts or seasons (grouping factors), as well as those taxa that contribute more to the similarity or dissimilarity.

To compare the effect of different conflicts on macroinvertebrate community structure and composition, a Multiple nonparametric regression on Bray-Curtis similarity distances were run for data set (taxonomic composition - $\log (x+1)$ transformed) from distance-based linear models (DISTLM) with the environmental data. Redundant 
physicochemical parameters were removed using the Spearman rank correlation coefficient $r$ (highly correlated variables based on a threshold value of $-0.6 \geq r \geq 0.7$ ). Akaike's information criterion (AIC) was used to extract variables that optimized the global AIC by significantly increasing the amount of explained variation (Akaike, 1974). For visual interpretation of the models in a multidimensional space, a distancebased redundancy analysis (dbRDA) was used, which generated ordination plots that illustrate associations between environmental variables and biological data. dbRDA provided bi-plots of biological and environmental data, using a multivariate multiple regression based upon Principal Coordinates Ordination of biological data axes (based on a similarity matrix using Euclidean distances) on predictor variables or environmental descriptors. Previously, step-wise regressions extracted the most significant environmental variables and stressors, predicting change in invertebrate data at different scales, and compared the relative dependence of macroinvertebrate data type on the groups of predictors.

The physicochemical data, prior to the statistical analyses, were evaluated for normality and homoscedasticity by using the Kolmogorov-Smirnov test, and when necessary appropriately transformed in order to meet the ANOVA assumptions (Zar, 1999). The water parameters were compared between type of conflict areas (Ref., C1, C2 and C3) and among seasons (wet and dry periods) using a one-way analysis of variance (oneway ANOVA). When significant differences were detected, the Tukey test for multiple comparisons was applied. The significance level of 5\% was considered in all tests. All analyses were carried out using PRIMER 6 software (PRIMER-E Ltd) (Clarke and Gorley, 2006), PERMANOVA+ for PRIMER software (Anderson et al., 2008), or STATISTICA 8.0 software (StatSoft, 2007). 


\section{RESULTS}

\subsection{Land capability and environmental land use conflicts}

The drainage density of River Sordo sub-basins is illustrated in Fig. 2a. Within the order-1 sub-basins (Fig. 1b), the average drainage density of leptosol areas $\left(D_{\mathrm{d}}=2.377\right.$ $\mathrm{km}^{-1}$; Tab. 4) is significantly different (5\% level) from the homologous value in the anthrosol areas $\left(D_{\mathrm{d}}=3.544 \mathrm{~km}^{-1}\right)$, and a similar scenario is exhibited for the order-3 sub-basins $\left(D_{\mathrm{d}}=2.799 \mathrm{~km}^{-1}\right.$ in the leptosols; $D_{\mathrm{d}}=4.277 \mathrm{~km}^{-1}$ in the anthrosols $)$. Further, the inspection of terrain slopes, illustrated in Fig. 2b, revealed that leptosol areas are also markedly different from anthrosol areas as regards this parameter, within order-3 sub-basins ( $S I=21.17 \%$ in the leptosols; $S I=32.80 \%$ in the anthrosols). Because $R N=D_{\mathrm{d}} \times S l$, the $R N$ coefficients of leptosol and anthrosol areas are radically different when the focus is put on order-3 sub-basins, with leptosol values being much lower than the anthrosol counterparts $(R N=61.81$ in the leptosols; $R N=137.98$ in the anthrosols). In view of these results, anthrosols are regarded as more limited on their potential uses than the leptosols.

To set up land capability within the River Sordo basin, the $R N$ coefficients estimated for the sub-basins were analyzed for their minimum $\left(R N_{\min }\right)$ and maximum $\left(R N_{\max }\right)$ scores, within the leptosol and anthrosol areas. Then, the amplitude of $R N$ values was determined (Amplitude $=R N_{\max }-R N_{\min }$ ) for each soil type and converted into the four pre-defined equal-range land capability classes (Class = Amplitude/4), the boundaries of which are depicted in Tab. 5. Finally, each sub-basin was allocated to a class considering its own $R N$ score. The results of land capability assessment are illustrated in Fig. 2c and make known that $70.25 \%$ of the River Sordo basin has a capability for agriculture while $23.04 \%$ is suited for livestock production, $4.96 \%$ for livestock production or afforestation, and $1.75 \%$ for afforestation. 
The analysis of land use conflicts (Fig. 2d) revealed that $2.077 \mathrm{~km}^{2}(4.07 \%)$ of the River Sordo basin is presently subject to a conflict of class $1(\mathrm{C} 1), 0.808 \mathrm{~km}^{2}(1.58 \%)$ to a conflict of class $2(\mathrm{C} 2)$, and $0.216 \mathrm{~km}^{2}(0.42 \%)$ to a conflict of class $3(\mathrm{C} 3)$.

\subsection{Biological condition of surface waters}

A total of 19056 macroinvertebrate organisms distributed by 81 families were collected during the sampling campaigns taken place at the sites represented in Fig. 2d. The counting of macroinvertebrates is provided as supplementary material. During the wet season, the number of collected and identified macroinvertebrates was $9023(47.4 \%, 81$ families), with Ephemeroptera (mayflies, 37.04\%), Diptera (midges, 18.26\%) and Trichoptera (caddisflies, 11.24\%) being the most represented taxa. In the dry season, a total of 10033 individuals were collected $(52.6 \%, 80$ families $)$, with mayflies $(30.59 \%)$, midges $(21.97 \%)$ and freshwater snails $(13.62 \%)$ being the most represented taxa. These results make it evident the replacement of caddisflies (mostly intolerants organisms) by freshwater snails (more tolerant individuals) in the transition between seasons. Apart from this switch, some differences were detected among the reference site and the sites located within the conflict areas. In the reference site, 1951 individuals belonging to 60 families were identified; Ephemeroptera (Mayflies - 23.73\%), Trichoptera (caddisflies - 17.63\%), Diptera (midges - 16.56\%), Coleoptera (beetles - 9.48\%) and Plecoptera (stoneflies $-9.23 \%$ ) were the most abundant taxa in these sites. In the areas of C1 conflict, 10391 macroinvertebrates belonging to 63 families were collected, mostly represented by mayflies $(37.43 \%)$, midges $(16.14 \%)$, stoneflies $(12.66 \%)$ and caddisflies (12.39\%). Finally, in the sites of C2 conflict 6714 macroinvertebrates pertaining to 62 families were collected, mainly represented by mayflies $(40.32 \%)$, snails $(22.65 \%)$ and midges $(22.03 \%)$. These results confirm that the structure of 
macroinvertebrate assemblage in the River Sordo basin can be altered by land use practices. Beraeidae, Brachycentridae, Calamoceratidae, Chloroperlidae,

Glossosomatidae, Heptageniidae, Leuctridae, Perlidae, Polycentropodidae, Scirtidae and Uenoidae were mainly found in the reference and $\mathrm{C} 1$ (extensive agriculture) conflict sites, while families such as Dixidae, Digesiidae, Empididae, Ephydridae, Haliplidae, Hydrobiidae, Hydrochidae, Hidroplilidae, Nepidae, Planorbidae, Psychodidae and Stratiomyiidae were found in the sites of C2 (intensive agriculture, vineyards) conflict. This is clear indication of a different response of macroinvertebrate taxa to different land uses.

Regardless the season all analysed metrics follow a general trend marked by negative correlations between metric scores and conflict class codes. It should be noted, however, that especially in the wet season all metrics revealed a small deviation from this trend by displaying an increase from the reference site to the Conflict 1 sites, followed by a sharp decrease towards the C2 sites (Fig. 3). Based on this observation, the reference site and the $\mathrm{C} 1$ sites may be seen as belonging to the same group. The biological quality assessed by $\operatorname{IPtI}_{\mathrm{N}}$ index ranged from High to Good, mainly for the Ref. and $\mathrm{C} 1$ classes, and from Moderate to Poor for the $\mathrm{C} 2$ class. It is remarkable that benthic macroinvertebrates respond in different ways to different conflict classes. So, it is noteworthy that there is a strong correlation ( $r$ and $p$ values of the linear fits) between macroinvertebrate assemblages and conflict classes for both periods (wet and dry), and that in the dry season the correlations are even stronger than in the wet period.

The NMDS ordination based on the abundance matrix of macroinvertebrate communities $(2 \mathrm{D}$ stress value $=0.14)$ exhibited a clear separation between conflict areas (reference and $\mathrm{C} 1$ versus $\mathrm{C} 2$ ) but with a low discriminatory power among seasons (wet versus dry). This is illustrated in Fig. 4, where it becomes clear that the groups of sites 
support different invertebrate communities. The ANOSIM testing identified a significant difference in the macroinvertebrate assemblages related to conflict areas (global $R=0.941 ; p$ value $=0.02 \%)$ but not among seasons $($ global $R=0.303 ; p$ value $=$ $0.06 \%)$. The distinction between the sites Ref. $+\mathrm{C} 1$ and $\mathrm{C} 2$ was confirmed with SIMPER tests performed in the NMDS ordination. Average dissimilarity between these sites was $62.21 \%$, which is obvious indication of a strong divergence in the macroinvertebrate assemblage. The most representative macroinvertebrate taxa (to a $70 \%$ cumulative percentage of dissimilarity) are presented in Tab. 6 .

The dbRDA analysis performed to determine associations between biological abundance and environmental predictors (descriptors of anthropogenic impacts) is illustrated in Fig. 5. It confirms a strong connection between the two data sets along the $1^{\text {st }}$ axis $(60.4 \%$ of fitted $)$ as well as along the $2^{\text {nd }}$ axis $(15.7 \%$ of fitted $)$. Along the $1^{\text {st }}$ axis, which explained $35.6 \%$ of the total variation, the sulphates, temperature and oxygen saturation $(\%)$ were the variables with the highest influence on the structure of macroinvertebrates in $\mathrm{C} 2$ sites, in opposition to the Ref. + C1 sites. On the other hand, the $2^{\text {nd }}$ axis (9.2\% of total variation) allowed the separation between seasons, although less evidently. In this case, temperature, TSS and turbidity variables were the variables exerting more influence during the dry period, while oxygen saturation and phosphates were the key variables during the wet period.

\subsection{Physicochemical quality of surface waters}

The mean values of physicochemical parameters in surface waters of River Sordo basin, measured at the sampling sites (Fig. 2d), as well as their comparison with quality standards defined in the Decree-Law no. 236/98, are summarized in Tab. 7. In the examined period, the water temperature ranged between $8.1-19.8^{\circ} \mathrm{C}$ and the average 
values for the wet and dry seasons were $11.8-15.7^{\circ} \mathrm{C}$. The analysis of variance (ANOVA $p<0.0001$ ) revealed significant differences between the sites, with the temperature being higher for those located farther from the basin headwaters. All parameters but $\mathrm{pH}$ complied with the limits reported in the Decree-Law no. 236/98 for Class A1 waters, defined as surface freshwaters to be used by humans, requiring physical treatment and disinfection before consumption. The lowest $\mathrm{pH}$ values obtained in the wet and dry periods (6.02 and 6.52, respectively) were related to an increase in domestic and farmland discharges along the river.

The water along the River Sordo showed significant variations (ANOVA $p<0.0001$ ) between the wet and dry periods, for $\mathrm{pH}$, dissolved oxygen, oxygen saturation, water temperature, ORP and conductivity. With regard to SST, phosphate and total alkalinity, the differences were significant but at lower probability levels (Tab. 7). Finally, the analysis of turbidity, nitrate and sulphate revealed no statistical differences between the two seasons. Apart from the variations among seasons, the water quality showed differences between sampling sites at ANOVA $p<0.0001$ and Tukey $p<0.05$, for electrical conductivity. This parameter increased from the reference site to the site located in the region of conflict class 3 (Fig. 2d), as follows (values in $\mu \mathrm{S} \mathrm{cm}^{-1}$ ): Ref15.683; $\mathrm{C} 1-42.670$ and $30.320 ; \mathrm{C} 2-122.080$ and 139.700; and $\mathrm{C} 3-146.930$. For the parameter phosphate, a split between the three groups was observed (Ref $+\mathrm{C} 1, \mathrm{C} 2, \mathrm{C} 3)$. Parameters $\mathrm{pH}$ and ORP formed two groups. The first group joined Ref and $\mathrm{C} 1$, the second group joined $\mathrm{C} 2$ and $\mathrm{C} 3$. Finally, $\mathrm{O}_{2}$ saturation, dissolved oxygen, turbidity, TSS, nitrate, sulphate and alkalinity revealed no significant differences between sites. 


\section{DISCUSSION}

\subsection{Environmental land use conflicts}

The deviation of actual land uses from natural land uses (environmental conflict) is linked to a more pronounced predisposition of soil to erosion (Pacheco et al., 2014). This has direct reflexes in desertification, sediment transport and elevated concentration of nutrients in surface water. In the River Sordo basin, the origin of contamination is mainly a consequence of nutrient leaching from fertilizers applied to irrigated crops or vineyards (diffuse source pollution).

The potential for soil erosion and river water contamination is directly related to drainage efficiency from uphill soils. In this study, the anthrosols (soils associated with vineyards and/or olive groves) showed larger drainage efficiency, when compared with leptosols. This happens because terrain slopes in areas covered by this soil type are steeper producing a faster runoff. Because of their larger drainage densities and ruggedness numbers $(R N)$, anthrosol areas potentiate more expressive landscape mobility, the reason why they are more restricted on their potential uses. According to Pandey et al. (2011), the higher the value of $R N$ the more likely is the soil to erode, with the production of large amounts of sediments. Valle Junior et al. (2012), when assessing potential land uses in the River Uberaba basin (Brazil), also correlated the $R N$ coefficient with larger slope degrees and drainage densities. The relationship between drainage density and susceptibility to erosion was even recognised by Nag and Chakraborty (2003). These authors recommended more conservative uses for high drainage density areas to prevent or minimize the transport of soil organic matter and pesticides of the hillsides to the aquatic system. 


\subsection{Biological condition of surface waters}

The importance of using macroinvertebrates as indicators of running waters is emphasized in numerous studies (Wright, 1995; Rosenberg et al., 2000; Bunn and Davies, 2000; Alba-Tercedor et al., 2002; Oliveira and Cortes, 2005; Oliveira and Cortes, 2006; Alonso, 2006; Oscoz et al., 2006; Varandas and Cortes, 2010). All the evaluated metrics - EPT taxa, $\mathrm{IPtI}_{\mathrm{N}}$ index, diversity of Shannon-Weaner and Evenness indices - resulted good candidates to assess land use conflicts (Fig. 3). Sites inserted in Ref and $\mathrm{C} 1$ conflict areas presented high to good physicochemical quality and low hydromorphological alterations, and were characterized by high values of diversity, EPT taxa and $\mathrm{IPtI}_{\mathrm{N}}$ index. This quality achieved by $\mathrm{C} 1$ sites may only be explained by the presence of riparian vegetation that absorbed much of the pollution load generated by different usages associated to extensive agriculture (rough unimproved grassland/pasture, rain fed crops and semi-subsistence farming). Odum et al. (1979) corroborate these results by telling that a subsidy-stress response may be a common outcome of riparian thinning and a low intensity of agriculture. The previous authors emphasize that initial increases in light, nutrients, and water temperatures increase periphyton biomass and macroinvertebrate abundance, with no obvious decline in diversity. Nevertheless, Quinn (2000) adds that the intensification of agriculture results in the loss of diversity and of sensitive species. In contrast to the previous sampling locals, C2 sites were impacted presenting a water quality below the defined for the A1 Class established in the Decree-Law no. 236/98 (Table 7) and consequently an ecological status which does not fulfil the demands of the EU Water Framework Directive (2000/60). The abrupt decline in the quality of these sites, when the conflict class goes down by a single step, can mainly be due to the total absence of riparian gallery and the resectioning/reinforcement of the banks. These artificial features prevent 
an expansion of the bed during floods, decreasing the diversity of aquatic and riparian habitats that are extremely important for macrobenthic communities. In two mediumsized river basins of southwestern Greece, Theodoropoulos and Iliopoulou-Georgudaki (2010) also observed significant impact of land use changes in the water quality, highlighting the key role of riparian vegetation for the cleaning up of surface waters. The same finding was noted by Allan et al. (1997) in mountain streams of temperate areas. They found that land use changes have resulted in profound modifications of running waters.

Agricultural activity in the eastern part of River Sordo basin is closely associated with the vineyard culture in which all land is exploited down to the river. Miserendino and Masi (2010) also found, for Patagonian low order streams, that the maintenance of good conditions of riparian vegetation adjacent to rivers will enhance water quality and the environment for highly endemic macroinvertebrate communities. Several other studies also showed that riparian vegetation plays a key role in the decontamination of river water.

In 78 basins across the Mid-Atlantic Highlands region, Jones et al. (2001) found that landscape metrics, particularly the proportion of agriculture in the catchment and forest in the riparian zone, explained $65 \%-84 \%$ of the variation in yields of nitrogen, phosphorus, and suspended sediments. Through the regeneration or maintenance of these ecotones, even with remnant vegetation within agricultural watersheds, it is possible to verify improvements in physical habitat structure and biotic health indices of riverine systems (Adams et al., 1995; Storey and Cowley, 1997; Lazorchak et al., 1998; Scarsbrook and Halliday, 1999; Tavzes et al., 2006; McCord et al., 2007; Theodoropoulos and Iliopoulou-Georgudaki, 2010). Since the riparian vegetation contributes to the retention of sediments and nutrients it undeniably has the ability to 
mitigate human impacts at larger scales (Jaworski, 1993). Gregory et al. (1991) and Naiman and Decamps (1997) stress that riparian management is particularly attractive because of the riparian zone's direct influences on stream condition via welldocumented pathways. This knowledge is reinforced by Lowrance et al. (1997) and Quinn et al. (2001) when saying that the riparian corridors promise benefits that are highly disproportionate to the land area required. In the present study, these findings were strengthened by the results obtained by NMDS ordination, based on the abundance of macroinvertebrates matrix. This analysis displayed a clear separation between conflict areas (reference $+\mathrm{C} 1$ versus $\mathrm{C} 2$ ) which confirms a tendency for the general decline in ecological quality with the increase of conflict class (Fig. 3). Both analyses disclosed that the conflict groups support different invertebrate communities. Although the NMDS analysis (Fig. 4) failed to show a clear separation between seasons (wet versus dry), some metrics showed a clear separation them. Metrics such as the ShannonWiener diversity, evenness, EPT taxa, and $\mathrm{IPtI}_{\mathrm{N}}$ index have achieved the highest values during the wet season, while metrics such as total number of families and total number of individuals took place during the dry period (Fig. 3). The environmental seasonality was an important factor for structuring the macroinvertebrate communities showing different compositions in both sampling periods. Tupinambás et al. (2014), in a study of the seasonal impact of daily flow peaking regimes on the macroinvertebrate community, in the lotic section downstream of the Itutinga reservoir on Rio Grande (State of Minas Gerais, southeastern Brazil), found similar patterns. They verified that highly significant differences existed between habitat parameters when dry and wet periods are compared, resulting in a temporal variation of macroinvertebrate fauna. Similarly to the present study, they also found that higher levels of richness and Shannon-Wiener diversity occurred during the wet season and in contrast the higher density values occurred during 
the dry period. The same evidence was observed by Righi-Cavallaro et al. (2010) when evaluating the effects of seasonality on diversity and structure of the macroinvertebrate fauna in riffles of a Neotropical chalk stream.

\subsection{Physicochemical quality of surface waters}

In what concerns to physicochemical water quality, nitrates and conductivity in the current study (Tab. 7) differentiated areas with and without conflict, verifying that the highest the conflict class the greatest the measured concentrations $(\mathrm{C} 1<\mathrm{C} 2<\mathrm{C} 3)$. The same trend was observed by Valle Junior et al. (2014 b) for $\mathrm{Na}^{+}, \mathrm{Ca}^{2+}, \mathrm{HCO}^{-}$and $\mathrm{NO}_{3}{ }^{-}$ when evaluating the quality of groundwater in the River Sordo basin. The electrical conductivity of water, related to the concentration of dissolved solids, is strictly dependent on the local geochemical characteristics, especially in degraded areas with high concentrations of organic matter and constant fertilization (Santos and Hernandez, 2013). Siqueira et al. (2012) and Abdala (2012), when assessing the quality of surface waters in areas of environmental conflict, found that among other physicochemical parameters electrical conductivity distinguished conflict areas and that increased concentrations of sulphate and nitrate in surface waters were directly correlated to agricultural contamination. Increasing concentrations of $\mathrm{NO}_{3}{ }^{-}$and $\mathrm{SO}_{4}{ }^{2-}$ in groundwater are directly correlated with agricultural contamination (Alencoão et al., 2004). Tundisi and Tundisi (2008) corroborated this observation as regards nitrates.

Relatively to phosphates in our study, its concentration differed only in areas of C2 and $\mathrm{C} 3$ (Tab. 7). The $\mathrm{pH}$ and ORP parameters allowed the differentiation between Ref. $+\mathrm{C} 1$ versus $\mathrm{C} 2$ and $\mathrm{C} 3$ conflict areas because they are affected by processes of water/rock interaction in which prevails the granitic lithology. A similar response was observed by Abdala (2012) when assessing the quality of surface waters in the River Lanoso and 
Uberaba basins. ORP values allowed us to evaluate the process of organic matter oxidation in the studied water body, indicating that there were better conditions in the rainy season due to the presence of higher levels of dissolved oxygen. However, during the dry period reduction processes were derived from anaerobic bacteria respiration due to the generated contamination (topical and diffuse). According to Fiorucci and Benedetti Filho (2005), values between $+200 \mathrm{mV}$ and $+600 \mathrm{mV}$ indicate a strongly oxidizing environment, while between $-100 \mathrm{mV}$ and $-200 \mathrm{mV}$ show reducing environment. Usually, the context of an unpolluted river is weakly oxidizing. Regarding the dissolved oxygen and saturation (Tab. 7), these parameters did not differentiate areas of environmental conflict because slopes along the main water course accelerate the movement of water, promoting oxygenation. Nevertheless, for sections with smaller slopes, dissolved oxygen is able to discriminate areas with different levels of environmental conflict (Abdala, 2012).

The first two axis of the dbRDA plot (Fig. 5) described $44.8 \%$ of total variation $(35.6 \%$ and $9.2 \%$ respectively for $1^{\text {st }}$ and $2^{\text {nd }}$ axes) revealing that sulphate, oxygen saturation, temperature, TSS, turbidity, and phosphates were the variables that contributed most to differentiate conflict classes and, to a lesser extent, to separate seasons (Fig. 5). Unlike our study, Righi-Cavallaro et al. (2010) found that temperature was not a differentiating parameter for the seasons, but on the other hand phosphorous, among other parameters, had different values in both periods, thus supporting part of our results.

\section{STRATEGIES FOR SOIL CONSERVATION AND WATER PROTECTION}

Conflict resolution may not necessarily require the restoration of these areas. Yet, in areas where conflicts exist and soil vulnerability is high, all the surrounding area is considered at risk, requiring accordingly the implementation of management measures with the ultimate goal of achieving a sustainable approach to protect the environment. In 
agreement to the European Commission (2014), since our knowledge of the interaction between the rivers and the landscape has been growing, urgent and effective solutions that respect nature are needed. According to the aforementioned directives, which oversees the respect for nature and sustainability of ecosystems, beneath are indicated some key measures for the conservation / protection of soil and water mainly in areas of agricultural activities on sloping lands (e.g. vineyards). According Comino et al. (2011), the erosion phenomena could be very dangerous in terms of soil loss from organic matter, of great importance for plants growth and landscape quality. So, the conservation and protection measures proposed specifically for the study area are:

- To regulate land use through measures that protect changes to existing patterns of land use ensuring that land is used according to its capability. Abandon cropland in highly erodible areas, leaving them to forest or grassland. According to DGADR (2009), Portugal does not have a global and comprehensive legislation on soil protection. In fact, neither at the European Community level such legislation exists, although numerous initiatives, programs and legislative measures exist on soil protection. Nevertheless, much work has yet to be done within the EU in the context of the $4^{\text {th }}$ Framework Programme for Research and Development.

- To implement the regulatory tool (Regulate Decree $n^{0}$ 2/2007, published officially in 17 January 2007) for acts of expansion or conversion of the local forest. Actually, this is a plan for forest management of Trás-os-Montes (Northern Portugal), which defines critical areas as regards risk of forest fire, sensitivity of soils to erosion, ecological relevance, etc., and establishes the set of species to be planted in those areas (and is now being used as heritage). So, 
initiatives like these should be extended to the whole country and not just be confined to a small region or a small group of farmers.

- To identify the critical areas to take measures for afforestation and erosion control. Due to overexploitation of soil mainly for plantation of vineyards and olive groves, sometimes not accompanied by the proper soil conservation practices, around $70 \%$ of Portuguese soils are threatened by erosion (Corine Land Cover, 1992), and 30\% show an accelerated process of degradation.

- To encourage through associations of farmers information sessions regarding the benefits of maintaining crop residue cover (cover of growing plants, crop residues or mulch) in the inter-rows, since it promotes the damping of rain drops (reducing the kinetic energy) decreasing the rate of entrainment of the soil particles (De Baets et al., 2006). This technique improves the stability of soil aggregation, increases the infiltration, and in the sequel mitigates soil water erosion by reducing runoff. Comino et al. (2011) reinforce this idea by stating that in soils with high water contents, the presence of vegetation can reduce the moisture level, avoiding the roots asphyxia phenomenon. However, with regard to vineyards it is noteworthy that when the winegrower chooses a natural (resident vegetation) or sown cover crop, information about plant species that adapt well to the relevant ecological and agronomical factors is fundamental in order to avoid negative impacts on wine grape production (Monteiro et al., 2012). These authors also point out that in Portugal the information about the importance of the methods applied and their implications for the dynamics of the weed community is scarce.

- To plant the new vineyards following the contour lines and terraces (conventional practices that farmers have invoked for centuries) instead of 
arranged along the lines of maximum gradient(known as vinha ao alto), as has been observed in the last 20-30 years, since it can reduce erosion by $50 \%$. Traditional farming practices ensured the long-term conservation of soil fertility. Erosion control measures, integration of organic matter, crop rotation, etc. were all traditional farming practices well known to the European farmers Montanarella (CCR-Ispra).

- To allow the regeneration of riparian vegetation or vegetated on lands near the water lines, or make its plantation with native riparian species, given the environmental, economic and social proven benefits. Maintaining riparian forest cover between the stream banks and the channel will promote resistance to erosion and improve habitat value. Regarding the vineyard, as already pointed out, terraces should be maintained. Nevertheless, along the watercourse leave buffer strips of variable width between 2 and 10 meters which does not make tillage or destruction of natural vegetation, according to Portuguese law, and gradually replace the walls by native vegetation using methods of natural engineering. The Portuguese law $n^{\circ} 16 / 2003$, published in the $4^{\text {th }}$ of June, imposes the preservation of margins to non-navigable water masses till the distance of ten meters, impeding the allocation of these soils to most activities, including agriculture. Despite the existence of this law, there is no effective inspection which invites many farmers to plant up to the water's edge. Restoring buffer strips represents an essential tool, in river rehabilitation, as they act as an environmental filter.

According to Fidelis and Roebeling (2014), regardless of what Portugal has been witnessing in recent years, namely the undertaking of a thorough reform of the legislative framework for water management and spatial planning systems, and the 
evolution of scientific knowledge regarding approaches to improve the combined analysis of land use and water resources, their wide use in current practice is still very poor. So, there is a need for finding new solutions for guidance to better plan and manage water and land uses to avoid soil and water degradation in the future. Accordingly, this kind of measures proposed could deliver benefits for both people and nature and could effectively provide other benefits derived from ecosystem services, such as leisure activities and nature protection, increasing life quality. Thus, they could help to maintain and restore biodiversity, by strengthening the functionality of both ecosystems, aquatic and terrestrial.

\section{CONCLUSIONS}

The ecological status in areas of land use conflict is not the one demanded by the Water Framework Directive 2000/60. For that reason, the establishment of action plans in order to meet the standards of good quality are required. In an attempt to improve water courses in areas of conflict, key measures are proposed for the conservation of soil and protection of surface water, to achieve a sustainable environment.

The role of riparian zone in water purification proved crucial in the present study, as sites surrounded by riparian vegetation presented good/excellent ecological quality $\left(\operatorname{IPtI}_{\mathrm{N}}\right)$, high values of diversity and EPT taxa, although they were impacted by nonpoint source pollution. In contrast, water contamination in areas of conflict is closely associated with a destruction of riparian gallery as a result of practices used in vine cultivation. Since the management of riparian corridors may be critical for the distribution of macrobenthic communities, the maintenance of good conditions of vegetation, adjacent to rivers, will be an asset in improving water quality. This study, like many others, came once more to prove the need for adopting agroforestry practices 
as an integrated set of land management that helps improving soil and water quality, enhancing wildlife habitat and sustaining land resources for long-term use, beyond the economic benefits to the landowner. Globally, this study illustrates the importance of the census of areas that are in a situation of environmental conflict through a simple and relatively inexpensive tool (cost effective framework) as presented here and that is based on the ruggedness number methodology $(R N)$. This approach allows to detect changes in patterns of land use which have a considerable impact on the quality of aquatic ecosystems (biological, physic-chemical and hydromorphological). It was also demonstrated that the assessment of conflict areas is important because it both contributes to a better understanding of the connection between land use and water quality and helps to select the relevant parameters for an efficient river basin management.

\section{ACKNOWLEDGEMENTS}

The authors would like to thank the Coordination of Improvement of Higher Education Personnel (CAPES) for the scholarship Process $n^{\circ} 10297 / 12-0$, to the University of Trás-os-Montes and Alto Douro (UTAD) and the Center for the Research and Technology of Agro-Environmental and Biological Sciences (CITAB) for technical support, and to the Federal Institute of Triângulo Mineiro (IFTM) for the support of a sabbatical year in Portugal. As regards the corresponding author, the research was funded by national funds (FCT - Portuguese Foundation for Science and Technology) under the strategic project of the Vila Real Chemistry Research Center (PEstOE/QUI/UI0616/2014). As regards the other authors, the research was supported by European Union funds (FEDER/COMPETE - Operational Competitiveness 
ms_Tables

4 October 2014

Programme) and by national funds (FCT - Portuguese Foundation for Science and Technology) under the project FCOMP-01-0124-FEDER-022692. 


\section{REFERENCES}

Abdala, V.L., 2012. Diagnóstico hídrico do rio Uberaba - MG como subsídio para a gestão das áreas de conflito ambiental. PhD in Agronomy. State University of São Paulo. Faculty of Agrarian and Veterinary Sciences. Jaboticabal. 64 pp (in Portuguese).

Abler D., Shortle J., Carmichel J. and Horan R., 2002. Climate change, agriculture and water quality in the Chesapeake Bay region. Climatic Change 55, 339-359.

Adams, T.O., Hook, D.D., Floyd M.A., 1995. Effectiveness monitoring of silvicultural best management practices in South Carolina. Southern Journal of Applied Forestry 19, 170-176.

Agroconsultores Ltd, Coba, Ltd, 1991. Carta de solos. Carta do uso actual da terra e carta de aptidão da terra do nordeste de Portugal. Universidade de Trás-os-Montes e Alto Douro. Projecto de desenvolvimento rural integrado de Trás-os-Montes e Alto Douro PDRITM). Universidade de Trás-os-Montes e Alto Douro (in Portuguese).

Akaike, H., 1974. A new look at the statistical model identification. IEEE Transactions on Automatic Control 19, 716-723.

Alba-Tercedor, J., Jáimez-Cuéllar, P., Álvarez, M., Avilés, J., Bonada, N., Casas, J., Mellado, A., Ortega, M., Pardo, I., Prat, N., Rieradevall, M., Robles, S., Sáinz-Cantero, C.E., SánchezOrtega, A., Suárez, M.L., Toro, M., Vidal-Abarca, M.R., Vivas, S., Zamora-Muñoz, C., 2002. Caracterización del estado ecológico de ríos mediterráneos ibéricos mediante el índice IBMWP (antes BMWP'). Limnetica 21, 175-185 (in Spanish).

Alencoão, A.M.P., Pacheco, F.A.L., Oliveira, A.S., 2004. Variação espacial de parâmetros hidroquímicos na bacia hidrográfica do rio Sordo (norte de Portugal). Revista da Faculdade de Ciências 1, 117-127 (in Portuguese).

Allan, J.D., Erickson, D.L., Fay, J., 1997. The influence on catchment land use on stream integrity across multiple spatial scales. Freshwater Biololgy 37, 149-161. 
Alonso, A., 2006. Valoración del efecto de la degradación ambiental sobre los macroinvertebrados bentónicos en la cabecera del río Henares. Ecosistemas 15, 1-5 (in Spanish).

Anderson, M.J., Gorley, R.N., Clarke, K.R., 2008. PERMANOVA + for PRIMER, guide to software and statistical methods. PRIMER-E Ltd., Plymouth, UK.

Barbour, M.T., Gerritsen, J., Snyder, B.D., Stribling, J.B., 1999. Rapid bioassessment protocols for use in streams and wadeable rivers: periphyton, benthic macroinvertebrates, and fish, 2nd. Ed. EPA 841-B-99-002. Environmental Protection Agency; Office of Water; Washington, D.C.

Benetti, C.J., Garrido, J., 2010. The influence of stream habitat and water quality on water beetles assemblages in two rivers in northwest Spain. Vie et Milieu 60, 53-63.

Bunn, S.E., Davies, P.M., 2000. Biological processes in running waters and their implications for the assessment of ecological integrity. Hydrobiologia 422-423, 61-70.

Clarke, K. R., Gorley, R. N., 2001. PRIMER version 5, User Manual / Tutorial. PRIMER-E Ltd., Plymouth, UK, 91 pp.

Clarke, K. R., Gorley, R. N., 2006. PRIMER version 6, User's manual: Plymouth Routines in Multivariate Ecological Research, PRIMER-E Ltd., Plymouth, UK, 190 pp.

Clarke, K.R., Warkick, R.M., 2001. Change in marine communities: An approach to statistical analysis and interpretation, 2nd edition. PRIMER-E Ltd., Plymouth, UK, 144 pp.

Comino, E., Marengo, P., Rolli, V., 2011. Soil erosion aspects in agricultural ecosystem. In: Godone, D. (Ed.), Soil Erosion Issues in Agriculture. Available from: http://www.extension.org.

Corine Land Cover, 2007. Corine Land Cover, version 9/2007. European Environment Agency, Denmark.

Cortes, R.M.V., Oliveira, S.V., Cabral, D.A., Santos, S., Ferreira, T., 2002. Different scales of analysis in classifying streams: From a multimetric towards an integrate system approach. Large Rivers. Archiv fuer Hydrobiologie. Supplement band 13, 209-224. 
Cortes, R.M.V., Hughes, S.J., Pereira, V.R., Varandas, S.G.P., 2013. Tools for bioindicator assessment in rivers: The importance of spatial scale, land use patterns and biotic integration. Ecological Indicators 34, 460-477.

De Baets, S., Poesen, J., Gyssels, G,. Knapen, A., 2006. Effects of grass roots on the erodibility of topsoils during concentrated flow. Geomorphololy 76, 54-67.

De Wit, P., Verheye, W.H., 2009. Land use planning for sustainable development. In: Verhey, W.H. (Ed.), Land use, land cover and soil sciences, volume iii. Encyclopedia of life support systems (EOLSS), 278 pp.

DGADR - Direção Geral de Agricultura e Desenvolvimento Rural, 2009. Diário da República, 1. ${ }^{\mathrm{a}}$ série - N. ${ }^{\circ} 159-18$ de Agosto de 2009 (in Portuguese).

Eastman, J.R., 2012. IDRISI Selva Manual. Clark Labs., Clark University, Worcester, MA, 322 pp. Provided as a PDF with the IDRISI Selva software package.

EEA, 2012. Territorial cohesion and water management in Europe: the spatial perspective. European Environmental Agency, Technical Report №4/2012, Copenhagen.

EMBRAPA-Empresa Brasileira de Pesquisa Agropecuária, Ltd., 1999. Centro Nacional de Pesquisa de Solos, Sistema Brasileiro de Classificação de Solos, Rio de Janeiro, 412 pp. (in Portuguese).

European Commission, 2014. Towards better environmental options in flood risk management. http://ec.europa.eu/environment/water/flood_risk/better_options.htm. Last updated: 20/02/2014.

Fernández-Díaz, M., Benetti, C.J., Garrido, J., 2008. Influence of iron and nitrate concentration in water on aquatic Coleoptera community structure: Application to the Avia river (Ourense, NW, Spain). Limnetica 27, 285-298.

Fidélis, T., Roebeling, P., 2013. Water resources and land use planning systems in Portugal Exploring better synergies through Ria de Aveiro. Land Use Policy 39, 84-95.

Fiorucci, A.R., Benedetti Filho, E., 2005. A importância do oxigênio dissolvido em ecossistemas aquáticos. Química Nova na Escola 22, 10-16 (in Portuguese). 
Gergel, S.E., Turner, M.G., Miller, J.R., Melack, J.M., Stanley, E.H., 2002. Landscape indicators of human impacts to riverine systems. Aquatic Science 64, 118-128.

Gregory, S.V., Swanson, F.J., McKee, W.A., Cummins, K.W., 1991. An ecosystem perspective of riparian zones: focus on links between land and water. BioScience 41, 540-51.

Hascic, I., Wu, J.J., 2006. Land use and watershed health in the United States. Land Economics $82,214-239$.

Hauer, F.R., Resh, V.H., 1996. Benthic macroinvertebrates, In: Hauer, F.R., Lamberti, G.A. (Eds.), Methods in stream ecology, pp. 339-369, Academy Press, New York, USA.

Hellawell, J.M., 1986. Biological indicators of freshwater pollution and environmental management. Pollution Monitoring Series, Elsevier Applied Science.

Horton, R., 1945. Erosional development of streams and their drainage basins: Hidrophysical approach to quantitative morphology. Geological Society of American Bulletin 56, 807-813.

INAG I.P., 2009. Critérios para a classificação do estado das massas de água superficiais - Rios e albufeiras. Ministério do Ambiente, Ordenamento do Território e do Desenvolvimento Regional. Instituto da Água, I. P., Portugal (in Portuguese)

ISRIC/UNEP, 1991. World map of the status of human-induced soil degradation (by Oldeman, L.R., Hakkeling, R.T.A., Sombroek, W.G.). Global Assessment of Soil Degradation (GLASOD), 2nd revised edition. Wageningen/Nairobi.

Jaworski, A., 1993. The application of the ecotone concept in defining nutrient management requirements for the upper Potomac River basin. Hydrobiologia 251, 341-349.

Jones, K.B., Neale, A.C., Nash, M.S., Van Remortel, R.D., Wickham, J.D., Ritters, K.H., O’Neil, R.T., 2001. Predicting nutrient and sediment loadings to streams from landscape metrics: a multiple watershed study from the United States Mid-Atlantic Region. Landscape Ecology 16, 301-312.

Lal, R., Stewart, B.A., 1990. Soil degradation. Springer-Verlag, New York.

Langpap, C., Hascic, I., Wu, J.J. 2008. Protecting watershed ecosystems through targeted local land use policies. American Journal of Agricultural Economics 90, 684-700. 
Lazorchak, J.M., Klemm, D.J., Peck, D.V., 1998. Environmental monitoring and assessment program-surface waters: Field operations and methods for measuring the ecological condition of Wadeable streams. EPA/620/R-94/004F, US Environmental Protection Agency. Office of Research and Development, Washington, DC.

Li, H., Wu, J., 2004. Use and misuse of landscape indices. Landscape Ecology 19, 389-399. Lowrance, R., Altier, L.S., Newbold, J.D., Schnabel, R.R., Groffman, P.M., Denver, J.M., Correll, D.L., Wendell Gilliam, J., Robinson, J.L., Brinsfield, R.B., Staver, K.W., Lucas, W., Todd, A.H., 1997. Water quality functions of riparian forest buffers in Chesapeake Bay watersheds. Environmental Management 21, 687-712.

Lucadamo, L., De Filippis, A., Mezzotero, A., Vizza, S., Gallo, L., 2007. Biological and chemical monitoring of some major Calabrian (Italy) Rivers. Environmental Monitoring and Assessment 146, 453-471.

Mandaville, S.M., 1979. Bioassessment of freshwaters using benthic macroinvertebrates-A primer, Project E-1, first ed. Soil \&Water Conservation Society of Metro Halifax, Viii, Chapters I-XXVII, Appendices A-D.

Marshall, J.C., Steward, A.L., Harch, B.D., 2006. Taxonomic resolution and quantification of freshwater macroinvertebrate samples from an Australian Dryland River: The benefits and costs of using species abundance. Hydrobiologia 572, 171-194

McCord, S.B., Grippo, R.S., Eagle, D.M., 2007. Effects of silviculture using best management practices on stream macroinvertebrate communities in three ecoregions of Arkansas, USA. Water, Air, \& Soil Pollution 184, 299-311.

Mello Filho, J.A., 1992. Direcionamento da ocupação da terra, pelo diagnóstico físico conservacionista, das micro-bacias hidrográficas dos rios Alambari e Sesmaria, em Resende, RJ. Graduation thesis, Federal University of Santa Maria, 50 pp (in Portuguese).

Mello Filho, J.A., Rocha, J.S.M., 1992. Diagnóstico físico-conservacionista da sub-bacia hidrográfica do rio Sesmaria. In: Congresso brasileiro de engenharia agrícola. Anais Santa Maria: Sociedade Brasileira de Engenharia Agrícola 21,78-2191 (in Portuguese).

MINITAB INC., 2003. Minitab Statistical software, release 14 for Windows. 
Miserendino, M.L., Masi, C.I., 2010. The effects of land use on environmental features and functional organization of macroinvertebrate communities in Patagonian low order streams. Ecological Indicators 10, 311-319.

Montanarella, L. (CCR-Ispra). Soil at the interface between Agriculture and Environment. In: Agriculture and Environment. The European Commission. http://ec.europa.eu/agriculture/envir/report/en/inter_en/report.htm

Monteiro, M., Caetano, F., Vasconcelos, T, Lopes, C.M., 2012. Vineyard weed community dynamics in the Dão wine growing region. Ciência e Técnica Vitivinícola 27(2). ISSN 02540223 .

Moreno, J.M., Vázquez, A., Vélez, R., 1998. Recent history of forest fires in Spain. In: Moreno J.M. (Ed.), Large Forest Fires, Backhuys Publishers, Leiden. 159-185.

Mouri, G., Takizawa, S., Oki, T., 2011. Spatial and temporal variation in nutrient parameters in stream water in a rural-urban catchment, Shikoku, Japan: Effects of land cover and human impact. Journal of Environmental Management 92, 1837-1848.

Murcott, S., 1997. Compilation of definition of sustainable development. AAAS Annual Conference, IIASA “Sustainability Indicators Symposium”, Seatle, WA, 12 pp.

Nag, S.K., Chakraborty, S., 2003. Influence of rock types and structures in the development of drainage network in hard rock area. Journal of the Indian Society of Remote Sensing 31, 25 35.

Naiman, R.J., Decamps, H., 1997. The ecology of interfaces: riparian zones. Annual Review of Ecology and Systematics 28, 621-58.

Nunes, A.N., 2012. Regional variability and driving forces behind forest fires in Portugal: An overview of the last three decades (1980-2009). Applied Geography 34,576-586.

Odum, E.P., Finn, J.T., Franz, E.H., 1979. Perturbation theory and the subsidy-stress gradient. BioScience 29, 349-52.

Oliveira, S.V., Cortes R.M.V., 2005. A biologically relevant habitat condition index for streams in northern Portugal. Aquatic Conservation: Marine and Freshwater Ecosystem 15, 189-210. 
Oliveira, S.V., Cortes, R.M.V., 2006. Combining logistic models with multivariate methods for the rapid biological assessment of rivers using macroinvertebrates. Environmental Monitoring and Assessment 112, 93-113.

Oscoz, J., Campos, F., Escala, M.C., 2006. Variación de la comunidad de macroinvertebrados bentónicos en relación con la calidad de las aguas. Limnetica 25, 683-692 (in Spanish).

Pacheco, F.A.L., Alencoão, A.M.P., 2006. Role of fractures in weathering of solid rocks: narrowing the gap between experimental and natural weathering rates. Journal of Hydrology $316,248-265$.

Pacheco, F.A.L., Sanches Fernandes, L.F., 2013. The multivariate statistical structure of DRASTIC model. Journal of Hydrology 476, 442-459.

Pacheco, F.A.L., Van der Weijden, C.H., 2014. Modeling rock weathering in small watersheds. Journal of Hydrology 513, 13-27.

Pacheco, A.L., Varandas, S.G., Fernandes, L.F.S., Valle Junior, R.F., 2014. Soil losses in rural watersheds with environmental land use conflicts. Science of the Total Environment 485$486,110-120$.

Pandey, A., Chowdary, V.M., Mal, B.C., Dabral, P.P., 2011. Remote sensing and GIS for identification of suitable sites for soil and water conservation structures. Land Degradation \& Development 22, 359-372.

Pearce, D., Markandya, A., Barbier, E., 1989. Blueprint for a green economy. Earthscan Publications Ltd, London.

Pérez-Bilbao, A., Garrido, J., 2009. Evaluación del estado de conservación de una zona LIC (Gándaras de Budiño, Red Natura, 2000) usando los coleópteros acuáticos como indicadores. Limnetica 28, 11-22 (in Spanish).

Pimentel, D., 1993. World soil erosion and conservation. Cambridge University Press, Cambridge, UK.

Pimentel, D., 2006. Soil erosion: a food and environmental threat. Environment, Development and Sustainability 8, 119-137. 
Pimentel, D., Kounang, N., 1998. Ecology of soil erosion in ecosystems. Ecosystems 1, 416426.

Pimentel, D., Harvey, C., Resosudarmo, P., Sinclair, K., Kurz, D., McNair M., Crist, S., Sphpritz, L., Fitton, L., Saffouri, R., Blair, R.,1995. Environmental and economic costs of soil erosion and conservation benefits. Science 267, 1117-1123.

Pissarra, T.C.T., Politano, W., Ferraudo, A.S., 2004. Avaliação de características morfométricas na relação solo-superfície da bacia hidrográfica do Córrego Rico. Jaboticabal (SP). Revista Brasileira de Ciência do Solo. Viçosa 28, 297-305 (in Portuguese).

Portugal, 2014. In: Encyclopaedia Britannica. Retrieved from http://www.britannica. com/EBchecked/topic/471439/Portugal.

Quinn, J.M., 2000. Effects of pastoral development. In: Collier, K.J., Winterbourn, M.J. (Eds.), New Zealand stream invertebrates: Ecology and implications for management. Caxton, Christchurch, NZ, pp. 208-29.

Quinn, J.M., Brown, P.M., Boyce, W., Mackay, S., Taylor, A., Fenton, T., 2001. Riparian zone classification for management of stream water quality and ecosystem health. Journal of American Water Resource Association 37, 1509-1515.

Righi-Cavallaro, K.O., Roche, K.F., Froehlich, O., Cavallaro, M.R., 2010. Structure of macroinvertebrate communities in riffles of a Neotropical karst stream in the wet and dry seasons. Acta Limnologica Brasiliensia 22, 306-316.

Rocha, J.S.M., Kurtz, S.M.J.M., 2001. Manual de manejo integrado de bacias hidrográficas. Editora da UFSM, Santa Maria, 282 pp (in Portuguese).

Roose, E., 1994. Introduction à la gestion conservatoire de l.eau, de la biomasse et de la fertilité des sols (GCES). Bulletin FAO 70 (in French).

Rosenberg, D.M., Resh, V.H., 1993. Introduction to freshwater biomonitoring and benthic macroinvertebrates, In: Rosenberg, D.M., Resh, V.H. (Eds.), Freshwater biomonitoring and benthic macroinvertebrates, Chapmann and Hall, New York, USA, pp. 1-9.

Rosenberg, D.M., Reynoldson, T.B., Resh, V.H., 2000. Establishing reference conditions in the Fraser River catchment, British Columbia, Canada, using the BEAST (Benthic Assessment 
of Sediment) predictive model. In: Wright, J.F., Sutcliffe, D.W., Furse, M.T. (Eds.), Assessing the biological quality of fresh waters: RIVPACS and other techniques. Freshwater Biological Association, Ambleside, Cumbria, U.K, pp. 181-194.

Roy, A.H., Rosemond, A.D., Paul, M.J., Leigh, D.S., Wallace, J.B., 2003. Stream macroinvertebrate response to catchment urbanization (Georgia, U.S.A.). Freshwater Biology 48, 329-346.

Rubio, J.L., 1987. Desertificación en la Comunidad Valenciana: Antecedentes históricos y situación actual de erosión. Revista Valenciana d'Estudis Autonomics 7, 231-258 (in Spanish).

Sanches Fernandes, L.F., Santos, C.M.M., Pereira, A.P., Moura, J.P., 2011. Model of management and decision support systems in the distribution of water for consumption case study in North Portugal. European Journal of Environmental and Civil Engineering 15(3), 411-426.

Sanches Fernandes, L.F., Seixas, F.J., Oliveira, P.C., Leitão, S., Moura, J.P., 2012. Climatechange impacts on nitrogen in a hydrographical basin in the northeast of Portugal. Fresenius Environmental Bulletin 21(12), 3643-3650.

Santos, G.O., Hermandez, F.B.T., 2013. Uso do solo e monitoramento dos recursos hídricos no córrego do Ipê, Ilha Solteira, SP. Revista Brasileira de Engenharia Agrícola e Ambiental 17, 60-68 (in Portuguese).

Scarsbrook, M.R., Halliday, J., 1999. Transition from pasture to native forest land use along stream continua: Effects on streams ecosystems and implications for restoration. New Zealand Journal of Marine and Freshwater Research 33, 293-310.

Schoonover, J.E., Lockaby, B.G., Pan, S., 2005. Changes in chemical and physical properties of stream water across an urban-rural gradient in western Georgia. Urban Ecosystems 8, 107 124.

Siqueira, H.E., Guidolini, J.F., Antunes, D.H., Oliveira, F.P., Valle Junior, R.F., 2012. Diagnóstico da qualidade da água em área de conflito de uso do solo na Microbacia Mangabeira, Uberaba-MG. Enciclopédia Biosfera 8, 1164-1178 (in Portuguese). 
Sliva, L., Williams, D.D., 2001. Buffer zone versus whole catchment approaches to studying land use impact on river water quality. Water Research $35,3462-3472$.

Slaymaker, O., 2010. Mountain hazards. In: Alcántara-Ayala, I., Goudie, A.S. (Eds.), Geomorphological hazards and disaster prevention. Cambridge University Press, Cambridge, UK, $291 \mathrm{p}$.

Sousa, M.B., 1982. Litoestratigrafia e estrutura do "Complexo Xisto-Grauváquico anteOrdovícico" - Grupo do Douro (Nordeste de Portugal). PhD Thesis, Coimbra University (in Portuguese).

Southerland, M.T., Stribling, J.B., 1995. Status of biological criteria development and implementation. In Davis, W.S., Simon, T.P. (Eds.). Biological assessment and criteria: Tools for water resource planning and decision making. Lewis Publishers, Boca Raton, Florida, pp. 81-96.

StatSoft, Inc., 2007. STATISTICA (data analysis software system), version 8.

Stockholm Declaration, 1972. Declaration of the United Nations Conference on the Human Environment (UNCHE). Stockholm, Sweden. U.N. Doc. A/Conf.48/14/Rev. 1(1973); 11 ILM 1416 (1972). http://untreaty.un.org/cod/avl/ha/dunche/dunche.html.

Storey, R.G., Cowley, D.R., 1997. Recovery of three New Zealand rural streams as they pass through native forest ecosystems. Hydrobiologia 353, 63-76.

Strahler, A.N., 1952. Hypsometric (area-altitude) analysis of erosional topology. Geological Society of America Bulletin 63, 1117-1142.

Strahler, A.N., 1957. Quantitative analysis of watershed geomorphology. Transactions of the American Geophysical Union 38(6), 913-920.

Stutter, M.I., Langan, S.J., Demars, B.O.L., 2007. River sediments provide a link between catchment pressures and ecological status in a mixed land use Scottish River system. Water Research 41, 2803-2815.

Tavzes, B., Urbanic, G., Toman, M., 2006. Biological and hydromorphological integrity of the small urban stream. Physics and Chemistry of the Earth 31, 1062-1074. 
Theodoropoulos, C., Iliopoulou-Georgudaki, J., 2010. Response of biota to land use changes and water quality degradation in two medium-sized river basins in southwestern Greece. Ecological Indicators 10, 1231-1238.

Thompson, R.M., Towsend, C.R., 2004. Land use influences on New Zealand stream communities effects on species composition, functional organization, and food-web structure. New Zealand Journal of Marine and Freshwater Research 38, 595-608.

Tu, J., 2011. Spatially varying relationships between land use and water quality across an urbanization gradient explored by geographically weighted regression. Applied Geography $31,376-392$.

Tundisi, J.G., Tundisi, T.M., 2008. Limnologia. Oficina de Textos, São Paulo, 631 pp (in Portuguese).

Tupinambás, T.H., Cortes, R.M.V., Varandas, S.G., Hughes, S.J., França, J.S., Callisto, M., 2014. Taxonomy, metrics or traits? Assessing macroinvertebrate community responses to daily flow peaking in a highly regulated Brazilian river system. Ecohydrology 7, 828-842.

Turner, M.G., 1990. Spatial and temporal analysis of landscape patterns. Landscape Ecology 4, $21-30$.

United Nations Conference on Environment and Development - UNCED, 1992. The Rio Declaration on Environment and Development.

Vallejo, R., (Ed.). 1997. La restauración de la cubierta vegetal en la Comunidad Valenciana. Fundación CEAM, Spain, 601 pp (in Spanish).

Valle Junior, R.F., 2008. Diagnóstico de áreas de risco de erosão e conflito de uso dos solos na bacia do rio Uberaba. PhD Thesis in Agronomy. State University of São Paulo. Faculty of Agrarian and Veterenary Sciences, Jaboticabal. 222 pp (in Portuguese).

Valle Junior, R.F., Galbiatti, J.A., Pissarra, T.C.T., Martins filho, M.V., 2012. Caracterização morfométrica da Bacia do Rio Uberaba e determinação do uso potencial do solo. Revista Caminhos de Geografia 13, 60-74 (in Portuguese). 
Valle Junior, R.F., Galbiatti, J.A., Pissarra, T.C.T., Martins Filho, M.V., 2013. Diagnóstico do conflito de uso e ocupação do solo na Bacia do Rio Uberaba. Global Science and Technology 6, 40-52 (in Portuguese).

Valle Junior, R.F, Varandas, S., Fernandes, L.F.S., Pacheco, F.A.L., 2014a. Environmental land use conflicts: a threat to soil conservation. Land Use Policy 41, 172-185.

Valle Junior, R.F, Varandas, S., Fernandes, L.F.S., Pacheco F.A.L., 2014b. Groundwater quality in rural watersheds with environmental land use conflicts. Science of Total Environment $493,812-827$.

Valle Júnior, R.F., Galbiatti, J.A., Martins Filho, M.V., Pissarra, T.C.T., 2010. Potencial de erosão da bacia do Rio Uberaba. Revista Engenharia Agrícola 30, 897-908 (in Portuguese).

Varandas, S.G., Cortes, R.M.V., 2010. Evaluating macroinvertebrate biological metrics for ecological assessment of streams in northern Portugal. Environmental Monitoring and Assessment 166, 201-221.

World Commission on Environment and Development - WCED, 1987. Our Common Future. Oxford University Press, Oxford, UK.

World Conservation Strategy - IUCN, 1980.

Wright, J.F., 1995. Development and use of a system for predicting the macroinvertebrate fauna in flowing waters. Australian Journal of Ecology 20, 181-197.

Zar, J.H., 1999. Biostatistical analysis. Prentice Hall, Upper Saddle River, N.J., 663 pp.

\section{References to websites}

http://www.igeoe.pt (assessed in 14 April 2014)

http://www.igeo.pt (assessed in 13 May 2014)

http://www.clarklabs.org (assessed in 14 April 2014) 
Tab. 1. Slope intervals and associated reliefs.

\begin{tabular}{cl}
\hline Slope class $(\%)$ & Relief description \\
\hline $0-5$ & Flat to smoothly undulated \\
$5-10$ & Smoothly undulated to undulated \\
$10-20$ & Undulated to considerably undulated \\
$20-47$ & Considerably undulated to strongly undulated \\
$>47$ & Strongly undulated to mountainous \\
\hline
\end{tabular}

Adapted from Embrapa (1999).

Tab. 2. Land capabilities (N), land uses (A) and associated classification codes, selected for the land use conflict analysis.

\begin{tabular}{lc} 
Land capability $(\mathrm{N})$ or land use (A) & Classification code (A, N) \\
\hline Agriculture & 1 \\
Pastures for livestock production & 2 \\
Pastures for livestock production / Forestry & 3 \\
Forestry & 4 \\
\hline
\end{tabular}

Adapted from Rocha and Kurtz (2001).

Tab. 3. Meteorological data referred to the sampling periods.

\begin{tabular}{cccc}
\hline Date & Season & $\begin{array}{c}\text { Average Monthly } \\
\text { Rainfall }(\mathrm{mm})\end{array}$ & $\begin{array}{c}\text { Rainfall accumulated during } \\
\text { the period of 7 days prior to } \\
\text { collection }(\mathrm{mm})\end{array}$ \\
\hline $18 / 03 / 2013$ & Wet & 108.1 & 37.0 \\
$15 / 04 / 2013$ & Wet & 219.4 & 25.8 \\
$15 / 05 / 2013$ & Wet & 16.7 & 8.7 \\
$14 / 06 / 2013$ & Dry & 3.7 & 1.1 \\
$16 / 07 / 2013$ & Dry & 4.5 & 1.6 \\
$20 / 08 / 2013$ & Dry & 0.0 & 0.0 \\
\hline
\end{tabular}

The data were obtained from http://snirh.apambiente.pt/. 
Tab. 4. Mean values, standard deviations (sd) and coefficients of variation (CV, \%) of sub-basin's terrain slope $(S l, \%)$, drainage density $\left(D_{\mathrm{d}}\right.$, km ${ }^{-}$ ${ }^{1}$ ) and ruggedness number $(R N)$, discriminated by sub-basin order (Fig. 1b) and soil type (Fig. 1c).

\begin{tabular}{|c|c|c|c|c|c|c|c|c|c|c|c|c|c|}
\hline & \multicolumn{13}{|c|}{ Sub-basin order } \\
\hline & & \multicolumn{3}{|c|}{ Order-1 } & \multicolumn{3}{|c|}{ Order-2 } & \multicolumn{3}{|c|}{ Order-3 } & \multicolumn{3}{|c|}{ Order-4 } \\
\hline & & $D_{\mathrm{d}}$ & $R N$ & $S l$ & $D_{\mathrm{d}}$ & $R N$ & $S l$ & $D_{\mathrm{d}}$ & $R N$ & $S l$ & $D_{\mathrm{d}}$ & $R N$ & $S I$ \\
\hline \multirow{2}{*}{$\begin{array}{l}\frac{n}{0} \\
0 \\
0 \\
0 \\
0 \\
0\end{array}$} & $\begin{array}{l}\text { Mean } \pm \\
\text { sd }\end{array}$ & $\begin{array}{c}2.377 \pm \\
1.016\end{array}$ & $\begin{array}{l}86.14(\mathrm{~ns}) \pm \\
\quad 64.28\end{array}$ & $\begin{array}{l}33.05(\mathrm{~ns}) \pm \\
14.56\end{array}$ & $\begin{array}{c}3.376(\mathrm{~ns}) \pm \\
1.692\end{array}$ & $\begin{array}{l}103.16(\mathrm{~ns}) \pm \\
89.04\end{array}$ & $\begin{array}{l}27.31(\mathrm{~ns}) \pm \\
10.25\end{array}$ & $\begin{array}{c}2.799 \pm \\
0.606\end{array}$ & $\begin{array}{c}\mathbf{6 1 . 8 1} \pm \\
29.33\end{array}$ & $\begin{array}{c}21.17 \pm \\
7.38\end{array}$ & $\begin{array}{l}3.972(\mathrm{~ns}) \pm \\
0.182\end{array}$ & $\begin{array}{l}79.31(\mathrm{~ns}) \pm \\
23.78\end{array}$ & $\begin{array}{l}21.14(\mathrm{~ns}) \pm \\
5.780\end{array}$ \\
\hline & $\mathrm{CV}$ & 42.7 & 74.6 & 44.05 & 0.501 & 86.3 & 37.5 & 21.6 & 47.4 & 34.8 & 4.58 & 29.98 & 27.3 \\
\hline \multirow{2}{*}{ 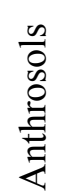 } & $\begin{array}{l}\text { Mean } \pm \\
\text { sd }\end{array}$ & $\begin{array}{c}3.544(0.018) \pm \\
1.902\end{array}$ & $\begin{array}{l}106.8(\mathrm{~ns}) \pm \\
64.71\end{array}$ & $\begin{array}{l}31.24(\mathrm{~ns}) \pm \\
14.32\end{array}$ & $\begin{array}{c}3.719(\mathrm{~ns}) \pm \\
1.202\end{array}$ & $\begin{array}{l}128.16(\mathrm{~ns}) \pm \\
63.34\end{array}$ & $\begin{array}{l}34.10(\mathrm{~ns}) \pm \\
14.05\end{array}$ & $\begin{array}{c}4.277(0.001) \pm \\
0.525\end{array}$ & $\begin{array}{c}\mathbf{1 3 7 . 9 8}(0.003) \pm \\
38.88\end{array}$ & $\begin{array}{l}32.8(0.04) \pm \\
9.55\end{array}$ & $\begin{array}{l}4.165(\mathrm{~ns}) \pm \\
0.055\end{array}$ & $\begin{array}{c}78.84(\mathrm{~ns}) \pm \\
17.37\end{array}$ & $\begin{array}{l}18.89(\mathrm{~ns}) \pm \\
3.952\end{array}$ \\
\hline & $\mathrm{CV}$ & 53.6 & 60.5 & 45.8 & 32.3 & 49.4 & 41.2 & 12.2 & 28.17 & 29.1 & 1.3 & 22.03 & 20.9 \\
\hline
\end{tabular}

Fluvisols were not included in the analysis because no sampling (macroinvertebrates, surface water) was carried out in areas covered by this soil type. Boldface values are significantly different among soil types (leptosols and anthrosols). The $p$ values (post hoc Turkey test) are given inside the brackets; ns means not significant to the test. 
Tab. 5. Boundaries of land capability classes (potential uses) as determined by the $R N$ methodology.

\begin{tabular}{ccc}
\hline \multirow{2}{*}{ Potential use } & \multicolumn{2}{c}{ Soil type } \\
\cline { 2 - 3 } & Anthrosol & Leptosol \\
\hline A & $14.53-68.64$ & $17.43-84.92$ \\
B & $68.64-122.75$ & $84.92-152.42$ \\
C & $122.75-176.87$ & $152.42-219.91$ \\
D & $176.87-230.98$ & $219.91-287.40$ \\
\hline
\end{tabular}

A - Agriculture; B - Pastures for livestock production; C - Pastures for livestock production / Forestry; D - Forestry.

Tab. 6. SIMPER results indicating the average contribution of the taxa responsible for the dissimilarities (up to 70\%) between conflict groups (Ref. $+\mathrm{C} 1$ and $\mathrm{C} 2$ ).

\begin{tabular}{lcc}
\hline Taxa & Contributed \% dissimilarity & Cumulative Contributed \% dissimilarity \\
\hline Leptophlebiidae & 5.55 & 5.55 \\
Hydrobiidae & 5.24 & 10.79 \\
Leuctridae & 3.99 & 14.77 \\
Heptageniidae & 3.78 & 18.56 \\
Limnephilidae & 3.45 & 22.01 \\
Nemouridae & 3.35 & 25.36 \\
Planariidae & 2.57 & 27.93 \\
Simuliidae & 2.56 & 30.49 \\
Baetidae & 2.52 & 33.01 \\
Chloroperlidae & 2.51 & 35.52 \\
Oligochaeta & 2.4 & 37.92 \\
Elmidae & 2.31 & 40.23 \\
Hydropsychidae & 2.29 & 42.53 \\
Hydracarina & 2.29 & 44.81 \\
Chironomidae & 2.18 & 47.00 \\
Sericostomatidae & 2.01 & 49.01 \\
Ephemerellidae & 1.99 & 51.00 \\
Mesoveliidae & 1.89 & 52.89 \\
Gerridae & 1.81 & 54.71 \\
Athericidae & 1.81 & 56.52 \\
Hydraenidae & 1.68 & 58.20 \\
Cordulegastridae & 1.64 & 59.84 \\
Uenoidae & 1.63 & 61.47 \\
Helicopsychidae & 1.59 & 63.06 \\
Perlodidae & 1.56 & 64.62 \\
Philopotamidae & 1.54 & 66.16 \\
Scirtidae & 1.54 & 67.70 \\
Leptoceridae & 1.52 & 69.21 \\
Polycentropodidae & 1.46 & 70.67 \\
\hline & &
\end{tabular}


Tab. 7. Mean values of physicochemical parameters in River Sordo Basin surface waters, measured at the sampling sites (Fig. 2d) and discriminating conflict classes and seasons.

\begin{tabular}{|c|c|c|c|c|c|c|c|c|c|c|c|c|c|}
\hline & & $\begin{array}{c}\text { Temperature } \\
\left({ }^{\circ} \mathrm{C}\right)\end{array}$ & $\begin{array}{c}\mathrm{O}_{2} \text { saturation } \\
(\%)\end{array}$ & $\begin{array}{c}\mathrm{O}_{2} \text { dissolved } \\
\left(\mathrm{mg} \mathrm{L}^{-1}\right)\end{array}$ & $\mathrm{pH}$ & $\begin{array}{l}\text { Redox potencial } \\
\text { (ORP, mV) }\end{array}$ & $\begin{array}{c}\text { Electrical } \\
\text { conductivity } \\
\left(\mu \mathrm{sm}^{-1}\right)\end{array}$ & $\begin{array}{l}\text { Turbidity } \\
\text { (NTU) }\end{array}$ & $\begin{array}{l}\text { Total suspended } \\
\text { solids } \\
\left(\mathrm{mg} \mathrm{L}^{-1}\right)\end{array}$ & $\begin{array}{c}\text { Nitrate } \\
\left(\mathrm{mg} \mathrm{L}^{-1}\right)\end{array}$ & $\begin{array}{c}\text { Phosphate } \\
\left(\mathrm{mg} \mathrm{L}^{-1}\right)\end{array}$ & $\begin{array}{l}\text { Sulphate } \\
\left(\mathrm{mg} \mathrm{L}^{-1}\right)\end{array}$ & $\begin{array}{c}\text { Alkalinity } \\
\left(\mathrm{mg} \mathrm{L}^{-1}\right)\end{array}$ \\
\hline \multirow{7}{*}{ 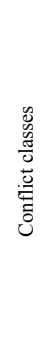 } & Sites & \multicolumn{12}{|c|}{ Mean \pm standard deviation } \\
\hline & Ref. & $12.5 b^{*} \pm 3.6$ & $96.4(\mathrm{~ns}) \pm 3.6$ & $9.2(\mathrm{~ns}) \pm 01.0$ & $5.8 b^{*} \pm 0.5$ & $62.9 \mathrm{a}^{*} \pm 25.5$ & $15.7 \mathrm{a}^{*} \pm 1.8$ & $0.3(\mathrm{~ns}) \pm 0.2$ & $0.17(\mathrm{~ns}) \pm 0.41$ & $7.63 a b^{*} \pm 2.53$ & $0.01 c^{*} \pm 0.01$ & $0.50 b^{*} \pm 0.55$ & $4.17 \mathrm{ab} * \pm 1.92$ \\
\hline & $\mathrm{Cla}$ & $12.2 b^{*} \pm 2.3$ & $88.7(\mathrm{~ns}) \pm 7.3$ & $8.7(\mathrm{~ns}) \pm 1.1$ & $5.7 b^{*} \pm 0.5$ & $66.5 \mathrm{a}^{*} \pm 22.7$ & $42.7 b^{*} \pm 12.1$ & $1.0(\mathrm{~ns}) \pm 0.3$ & $0.50(\mathrm{~ns}) \pm 0.55$ & $8.28 \mathrm{ab}^{*} \pm 3.63$ & $0.02 c^{*} \pm 0.02$ & $0.00 b^{*} \pm 0.00$ & $2.87 \mathrm{ab} * \pm 1.25$ \\
\hline & $\mathrm{Clb}$ & $11.5 b^{*} \pm 2.0$ & $91.8(\mathrm{~ns}) \pm 8.7$ & $9.1(\mathrm{~ns}) \pm 1.2$ & $5.5 b^{*} \pm 0.3$ & $78.5 \mathrm{a}^{*} \pm 11.9$ & $30.3 b^{*} \pm 11.7$ & $2.5(\mathrm{~ns}) \pm 4.1$ & $1.83(\mathrm{~ns}) \pm 3.60$ & $10.92 b^{*} \pm 4.85$ & $0.02 c^{*} \pm 0.01$ & $17.17 \mathrm{a}^{*} \pm 2.48$ & $11.18 \mathrm{~b}^{*} \pm 3.84$ \\
\hline & $\mathrm{C} 2 \mathrm{a}$ & $15.3 \mathrm{ab}^{*} \pm 3.1$ & $97.3(\mathrm{~ns}) \pm 3.6$ & $9.5(\mathrm{~ns}) \pm 0.9$ & $6.9 \mathrm{a}^{*} \pm 0.4$ & $5.0 b^{*} \pm 11.9$ & $122.1 c^{*} \pm 4.7$ & $1.3(\mathrm{~ns}) \pm 1.1$ & $0.83(\mathrm{~ns}) \pm 0.75$ & $18.85 \mathrm{c}^{*} \pm 3.27$ & $0.19 a^{*} \pm 0.04$ & $17.35 a^{*} \pm 7.67$ & $13.70 b^{*} \pm 6.54$ \\
\hline & $\mathrm{C} 2 \mathrm{~b}$ & $16.6 \mathrm{a}^{*} \pm 2.8$ & $95.9(\mathrm{~ns}) \pm 4.1$ & $9.1(\mathrm{~ns}) \pm 0.9$ & $6.9 \mathrm{a}^{*} \pm 0.4$ & $4.8 \mathrm{~b}^{*} \pm 16.7$ & $139.7 c^{*} \pm 27.0$ & $2.0(\mathrm{~ns}) \pm 2.2$ & 0.50 (ns) \pm 0.55 & $7.63 \mathrm{ab}^{*} \pm 2.53$ & $0.18 \mathrm{a}^{*} \pm 0.02$ & $0.50 b^{*} \pm 0.55$ & $4.17 \mathrm{ab} * \pm 1.92$ \\
\hline & $\mathrm{C} 3$ & $14.6 \mathrm{ab}^{*} \pm 2.3$ & $94.3(\mathrm{~ns}) \pm 2.3$ & $9.3(\mathrm{~ns}) \pm 0.6$ & $6.8 a^{*} \pm 0.4$ & $8.6 b^{*} \pm 25.0$ & $146.9 \mathrm{~d}^{*} \pm 12.7$ & $0.8(\mathrm{~ns}) \pm 1.0$ & $0.50(\mathrm{~ns}) \pm 1.23$ & $14.35 b^{*} \pm 1.08$ & $0.05 b^{*} \pm 0.01$ & $22.83 \mathrm{a}^{*} \pm 12.50$ & $15.05 b^{*} \pm 9.66$ \\
\hline \multirow{3}{*}{ 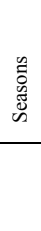 } & Dry & $15.7^{*} \pm 2.6$ & $90.6^{*} \pm 6.1$ & $9.87^{*} \pm 0.38$ & $6.5^{*} \pm 0.8$ & $23.5^{*} \pm 38.9$ & $91.1 * \pm 60.0$ & $1.3(\mathrm{~ns}) \pm 2.4$ & $10.45(\mathrm{~ns}) \pm 4.99$ & $10.45(\mathrm{~ns}) \pm 4.99$ & $0.07^{* * *} \pm 0.07$ & $10.34(\mathrm{~ns}) \pm 13.13$ & $10.67^{* *} \pm 8.50$ \\
\hline & Wet & $11.8^{*} \pm 2.3$ & $97.5^{*} \pm 2.3$ & $8.43 * \pm 0.68$ & $6.0^{*} \pm 0.7$ & $48.7^{*} \pm 35.4$ & $74.7 * \pm 53.7$ & $1.4(\mathrm{~ns}) \pm 1.4$ & $11.18(\mathrm{~ns}) \pm 6.21$ & $11.18(\mathrm{~ns}) \pm 6.21$ & $0.06 * * * \pm 0.06$ & $9.00(\mathrm{~ns}) \pm 9.38$ & $5.70^{* *} \pm 4.46$ \\
\hline & $\begin{array}{c}\text { Decree-Law } \\
\text { no. } 236 / 98 \\
\text { Class A1 }\end{array}$ & 22.0 & 70 & Not established & $6.5-8.5$ & Not established & 1000 & Not established & 25 & 25 & 0.17 & 150 & Not established \\
\hline
\end{tabular}

The lowercase letters ( $\mathrm{a}$ and $\mathrm{b}$ ) associated with the sampling sites identify different sites within the same conflict class. The conflict classes are represented by the following codes: Ref. - no conflict or reference class, $\mathrm{C} 1$ - Conflict class 1 , and $\mathrm{C} 2$ - Conflict class 2 . For the sake of comparison, the table includes threshold values for the analysed parameters as defined in the Portuguese legislation (Decree-law no. 236/98); they are the maximum values recommended for Class A1 waters, defined as surface freshwaters for human consumption. The means with the same letter are not significantly different from each other (Tukey test, $\mathrm{p}<0.05$ ); (ns) means not significant to test; the significance of values is in keeping with the ANOVA one-way $F$ test $(* * * p<0.0001, * * p<0.01$, and $* p<0.03)$. 


\section{FIGURE CAPTIONS}

2 Fig 1. The River Sordo basin: (a) Location, Digital Elevation Model displaying the relief and 3 climatic contours (precipitation and temperature); (b) Sub-basins discriminating the Strahler 4 order (Strahler, 1957); (c) Soil map; and (d) Land use map in 2007.

Fig. 2. Results of land capability and land use conflict modeling: (a) Average mean slopes of the 53 sub-basins; (b) Average drainage densities of of the 53 sub-basins; (c) Land capability map based on the RN methodology (product of slope and drainage density). (d) Map of land use conflicts illustrating the location of the sampling sites (river reaches). The symbols represent sites with different conflicts (Ref: Reference, C1: Conflict class 1, C2: Conflict class 2). The lowercase letters ( $a$ and $b$ ) associated with the sampling sites identify different sites within the same conflict class.

Fig. 3. Major correlations between biological data (A - EPT taxa richness: number of families; B - IPtIN index C - diversity: Shannon-Wiener; D - Evenness index) and conflict classes. Each spot (graphs a, b, c and d) represents one site at one season and the line drawn represents the linear equation that best fits the data. Note that $\mathrm{C} 2 \mathrm{~b}$ was dried during the month of August, the reason why the sampling was not executed in that period. Symbols represent sites with different conflicts (Ref: Reference, C1: Conflict class 1, C2: Conflict class 2).

Fig. 4. NMDS ordination plot of all sampled sites showing a clear separation between conflict classes (Ref. $+\mathrm{C} 1$ ) and to a less extent between seasons (wet versus dry). The acronyms used consist of two parts: the first refers to the season and the second is the class of conflicts (e.g. wet1).

Fig. 5. dbRDA plot illustrating the DistLM model based on biological data and environmental variables under AIC criterion. The acronyms used consist of two parts: the first refers to the season and the second is the class of conflicts (e.g. wet1). 


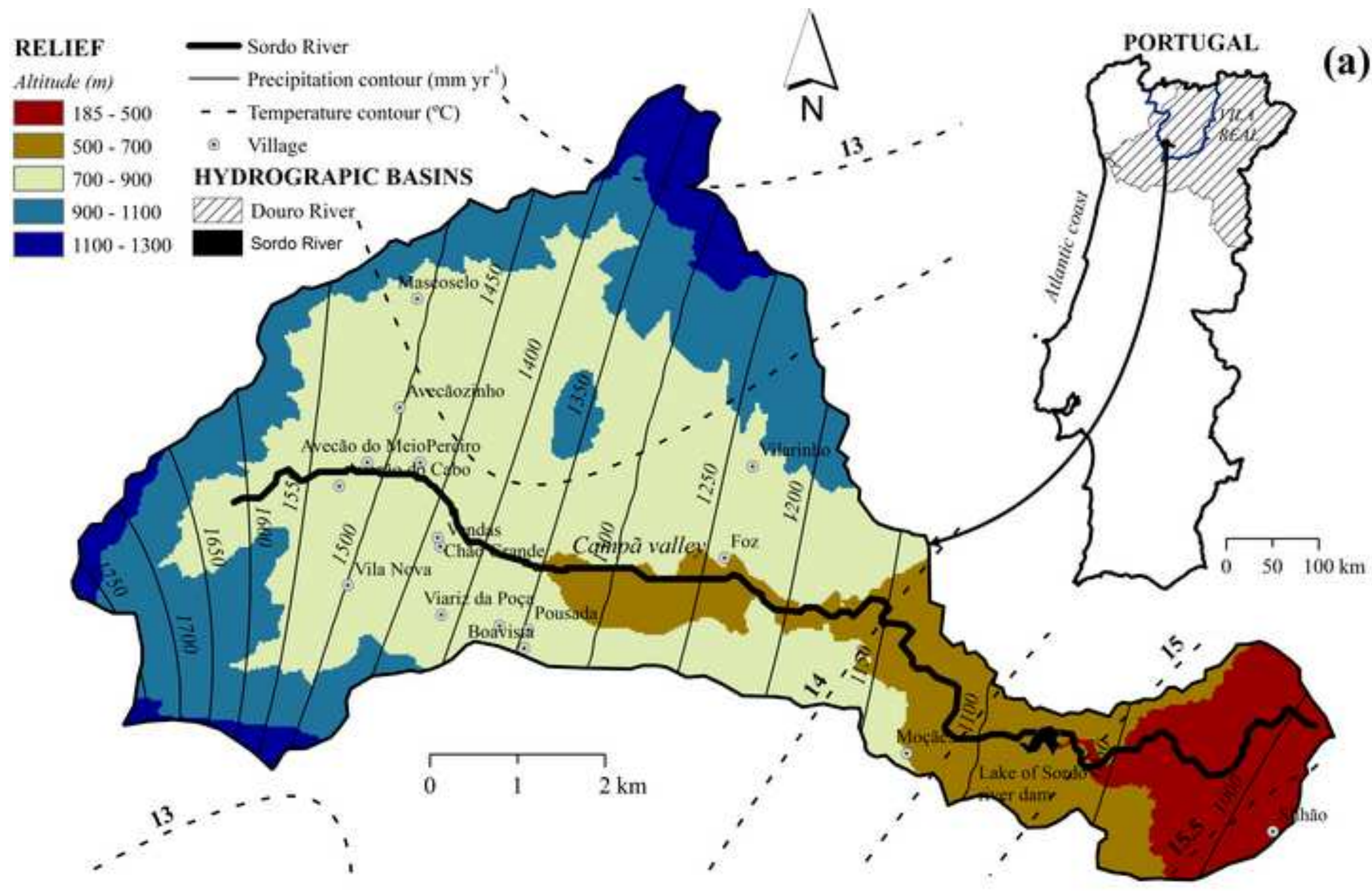




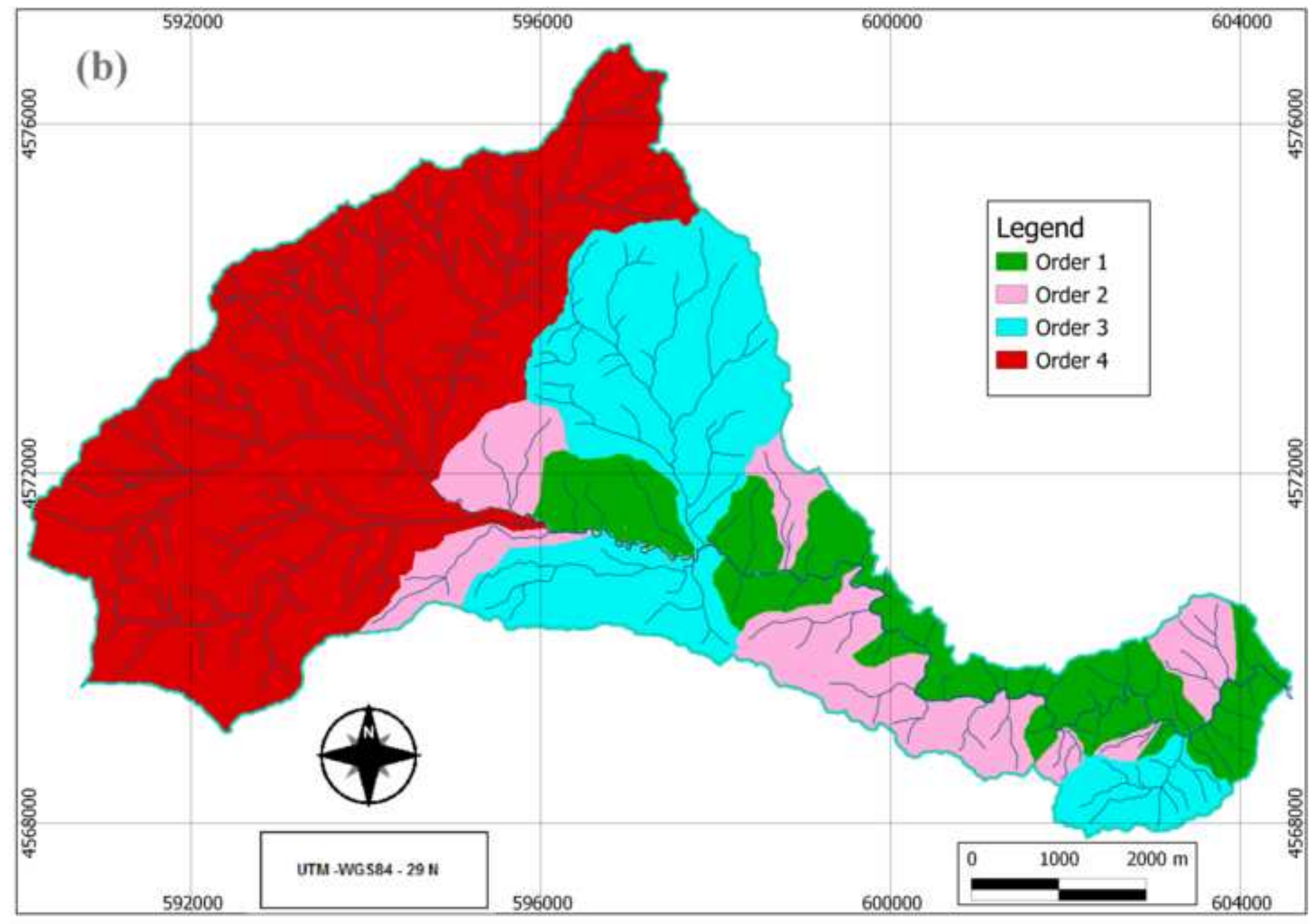




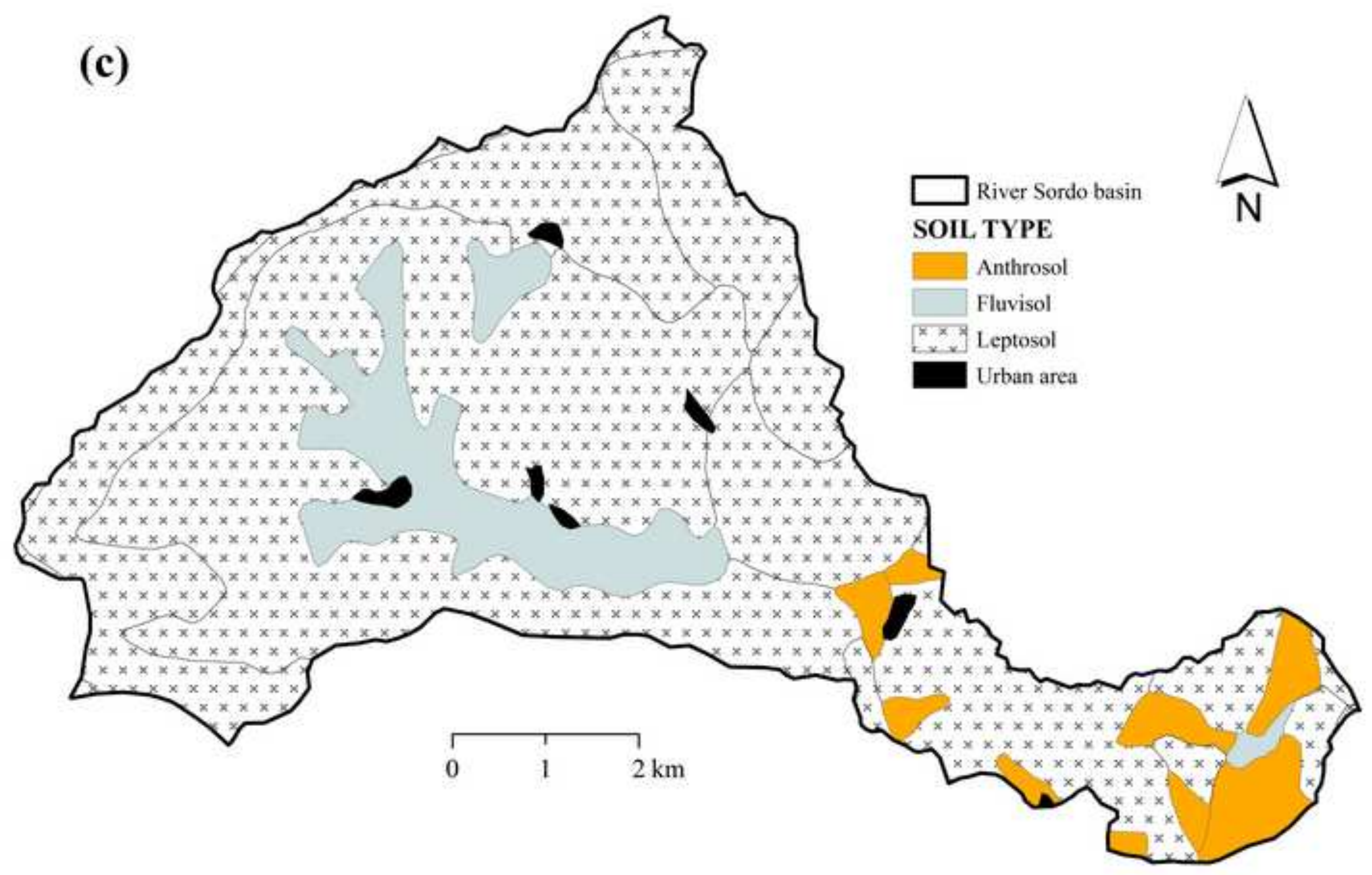




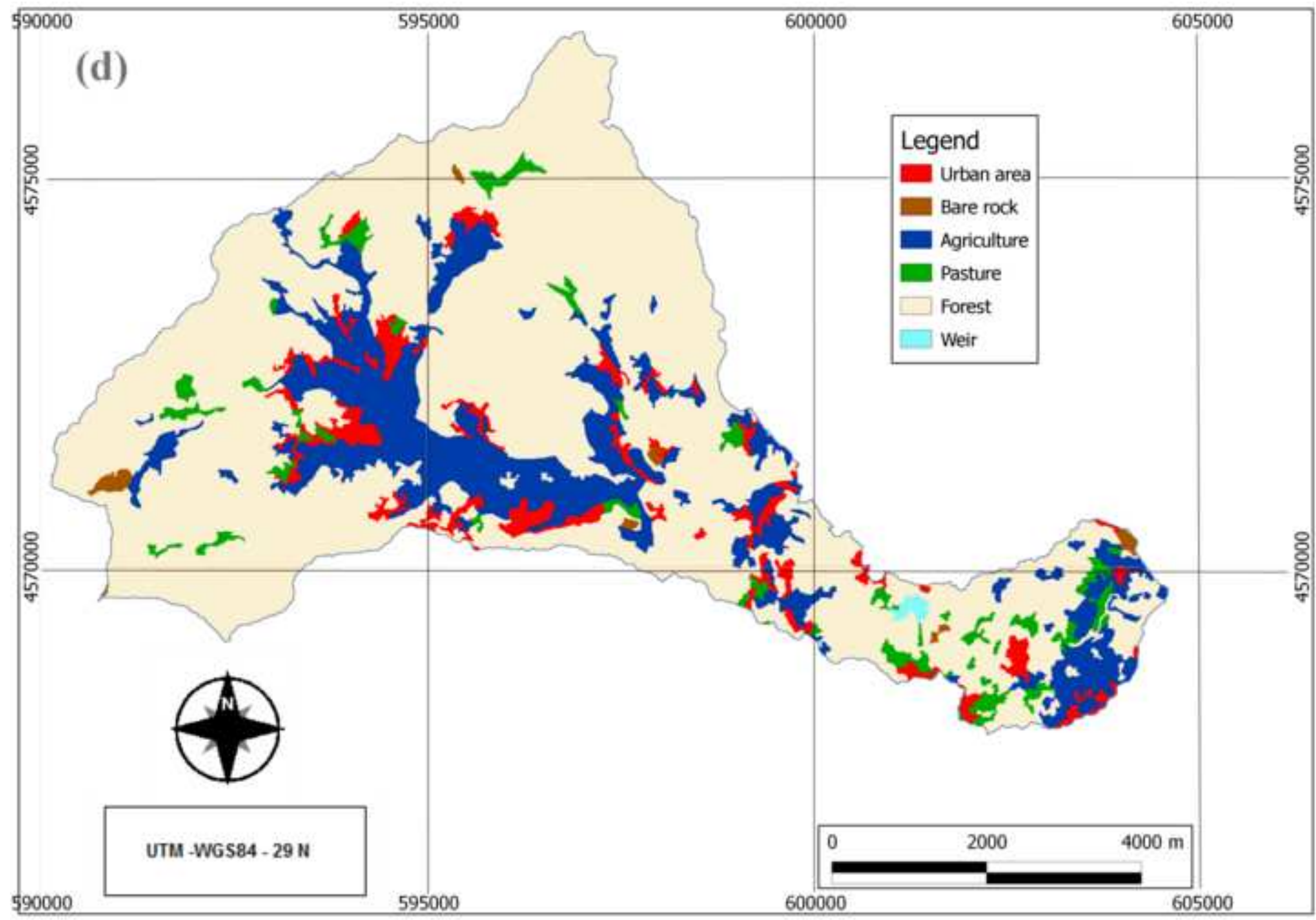




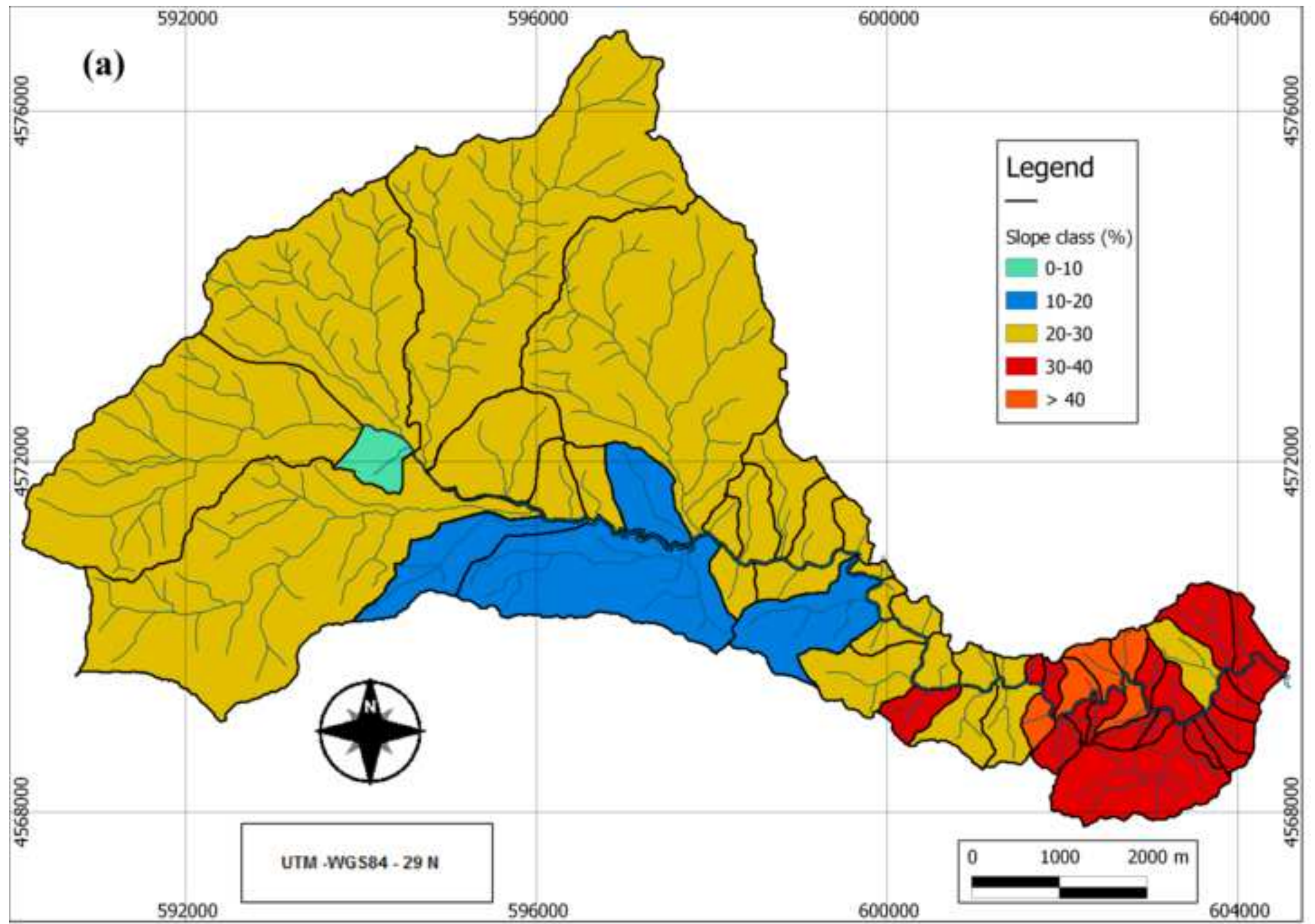




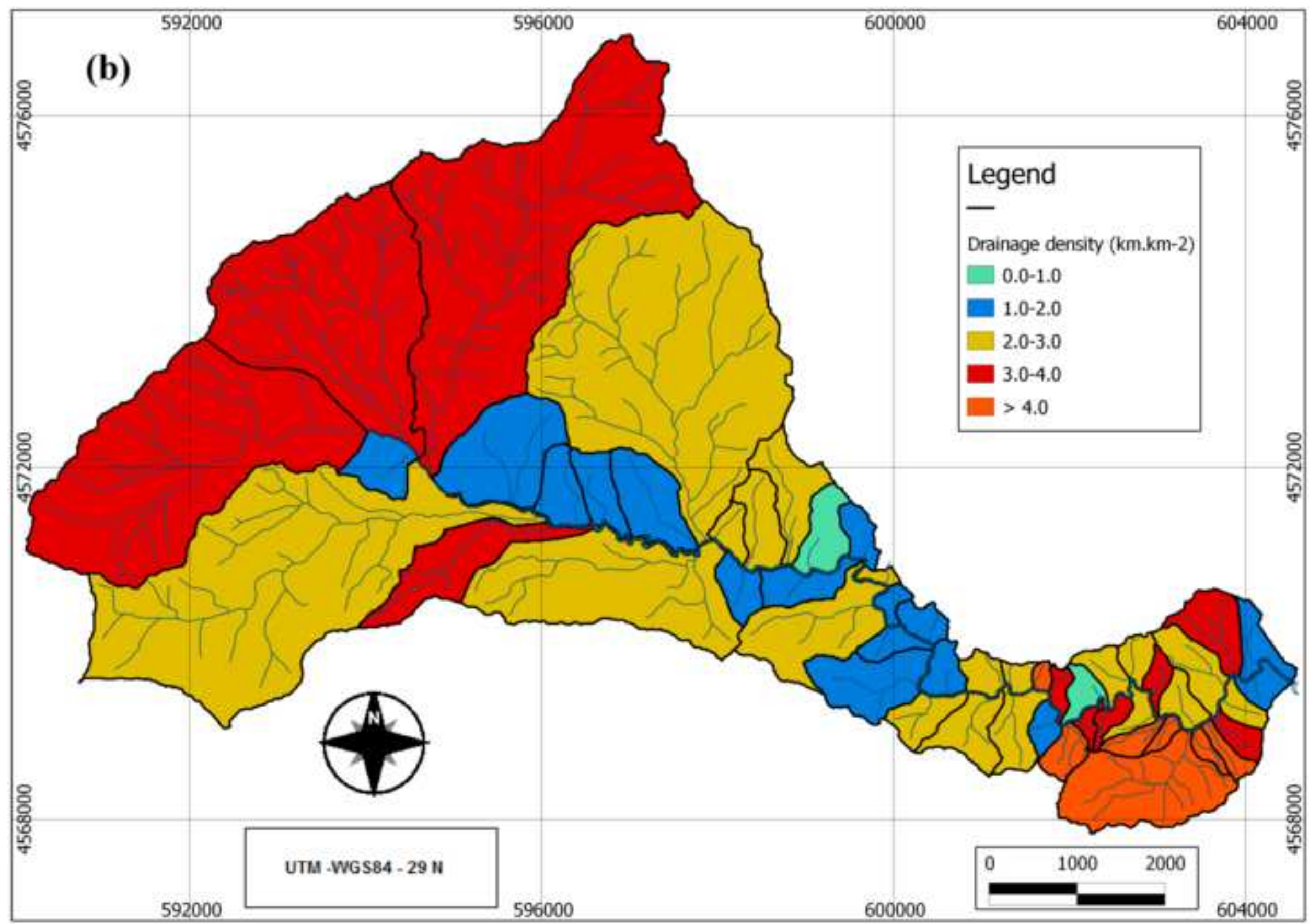




\section{Figure 2c

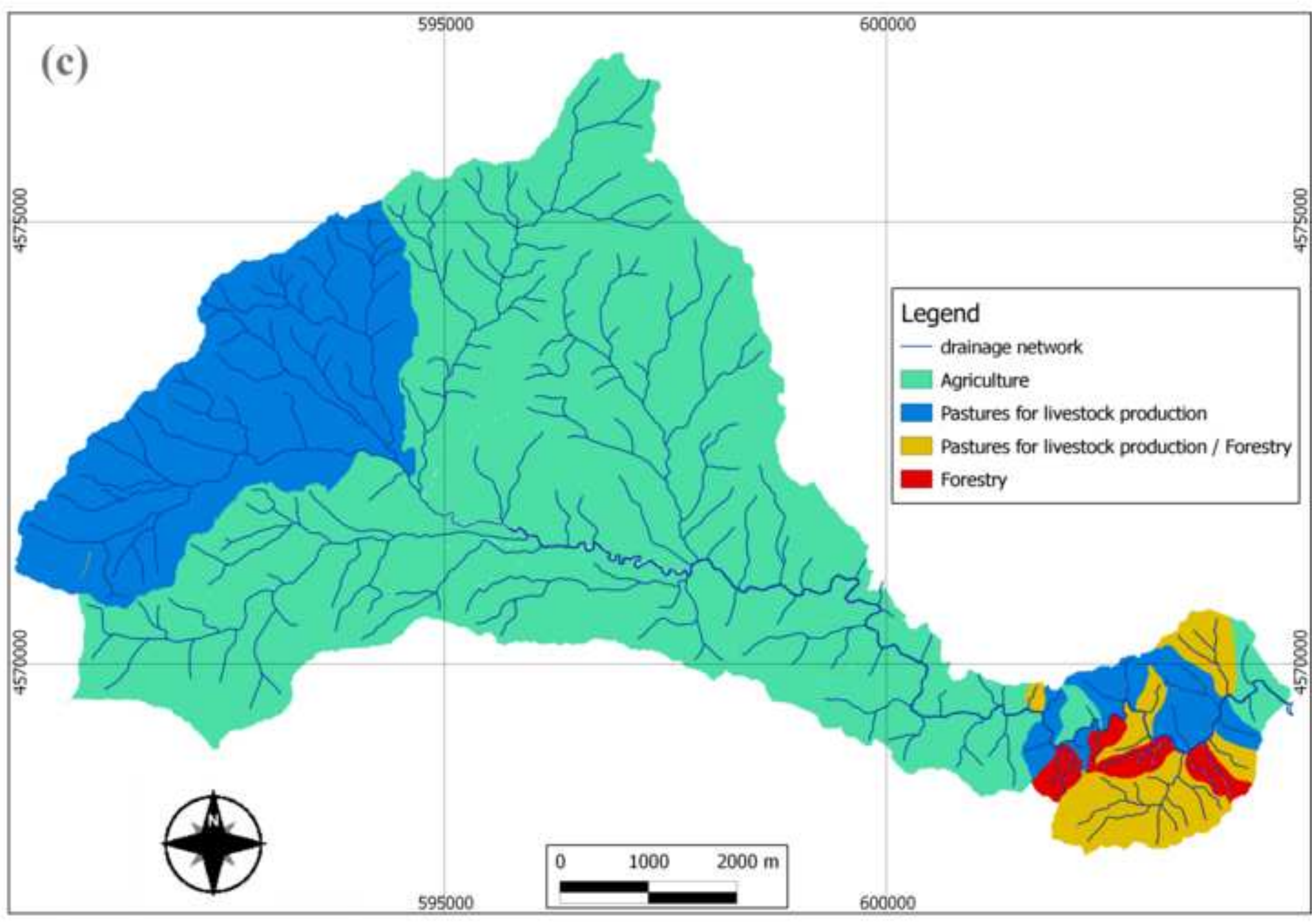




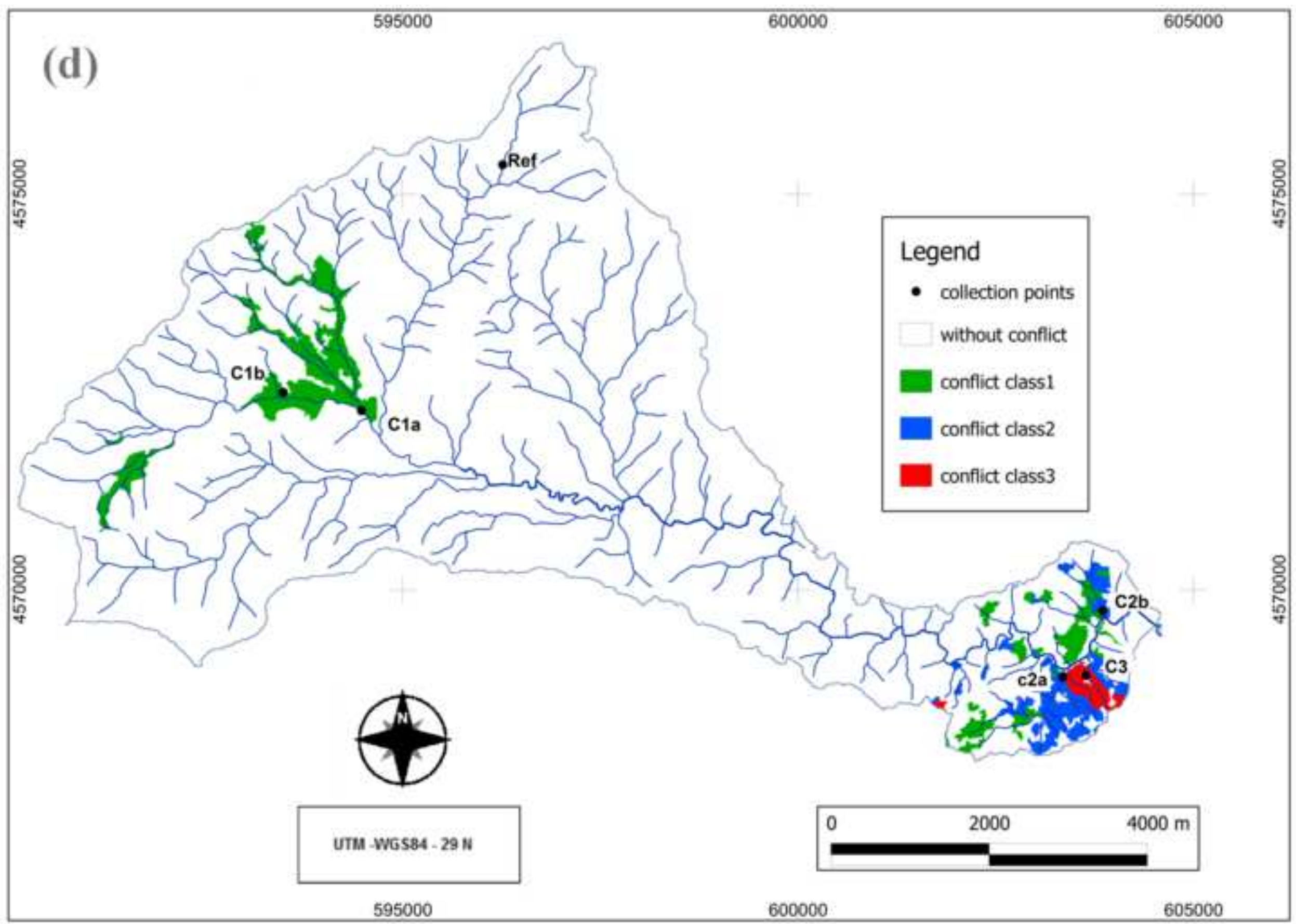



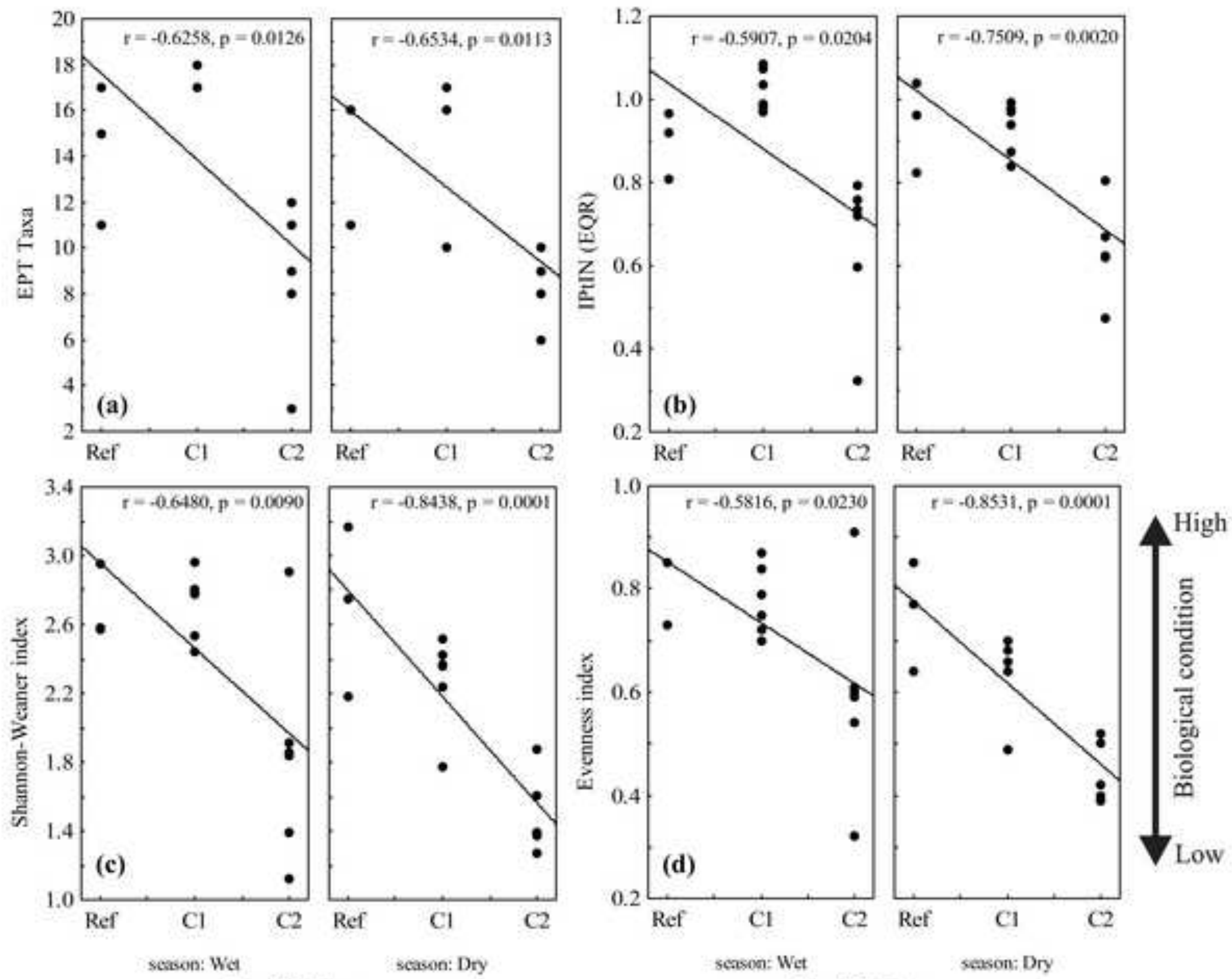

Conflict class

\section{Conflict class}

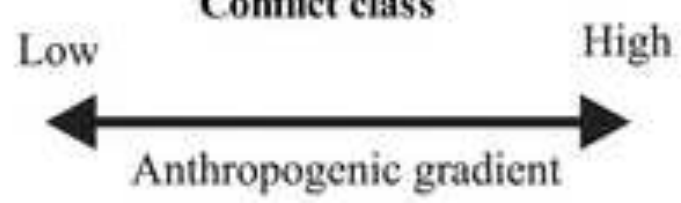




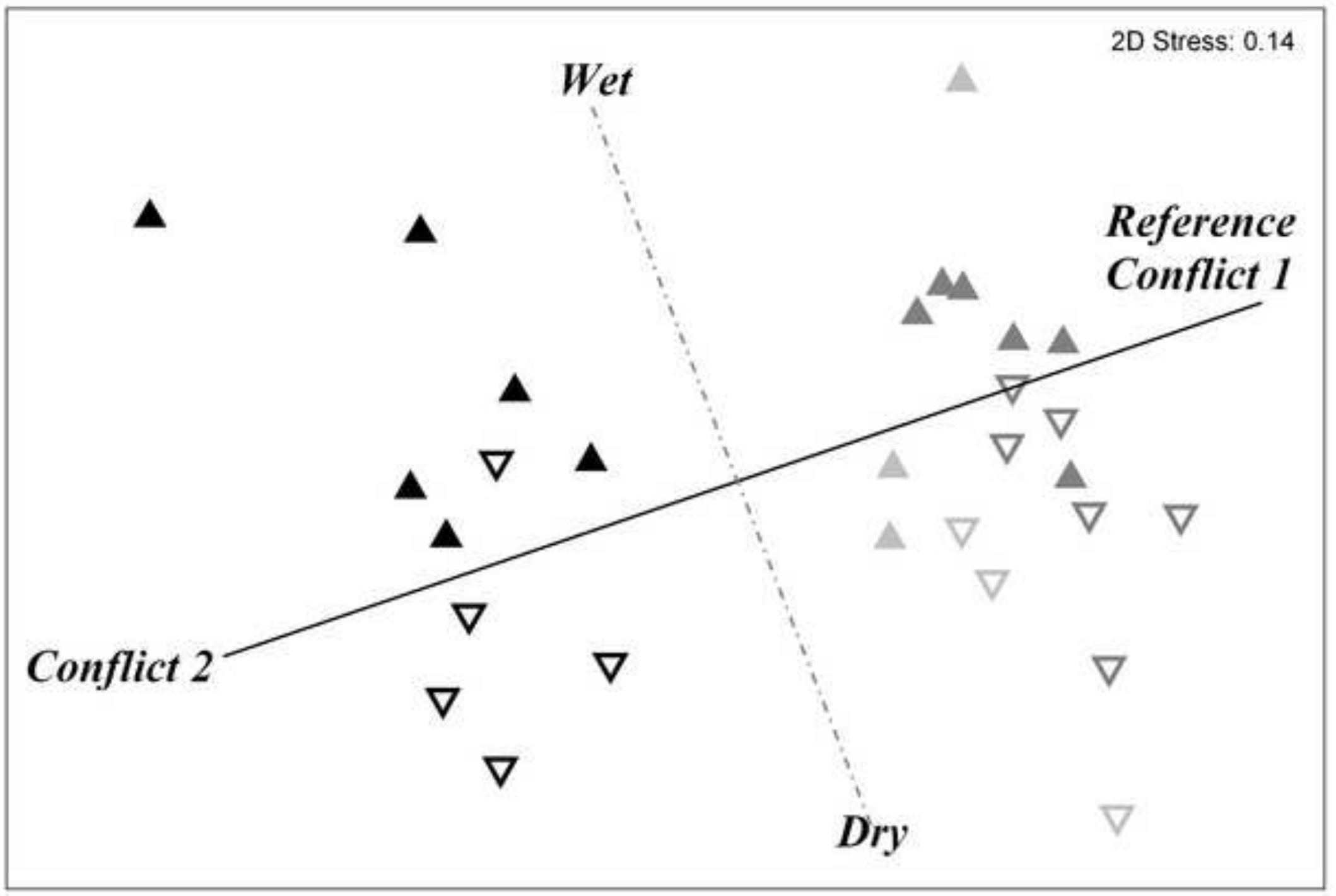

Season/Conflit

$\Delta$ wetRef

A wetl

A wet2

$\nabla$ dryRef

$\nabla$ dryl

$\nabla$ dry 2 


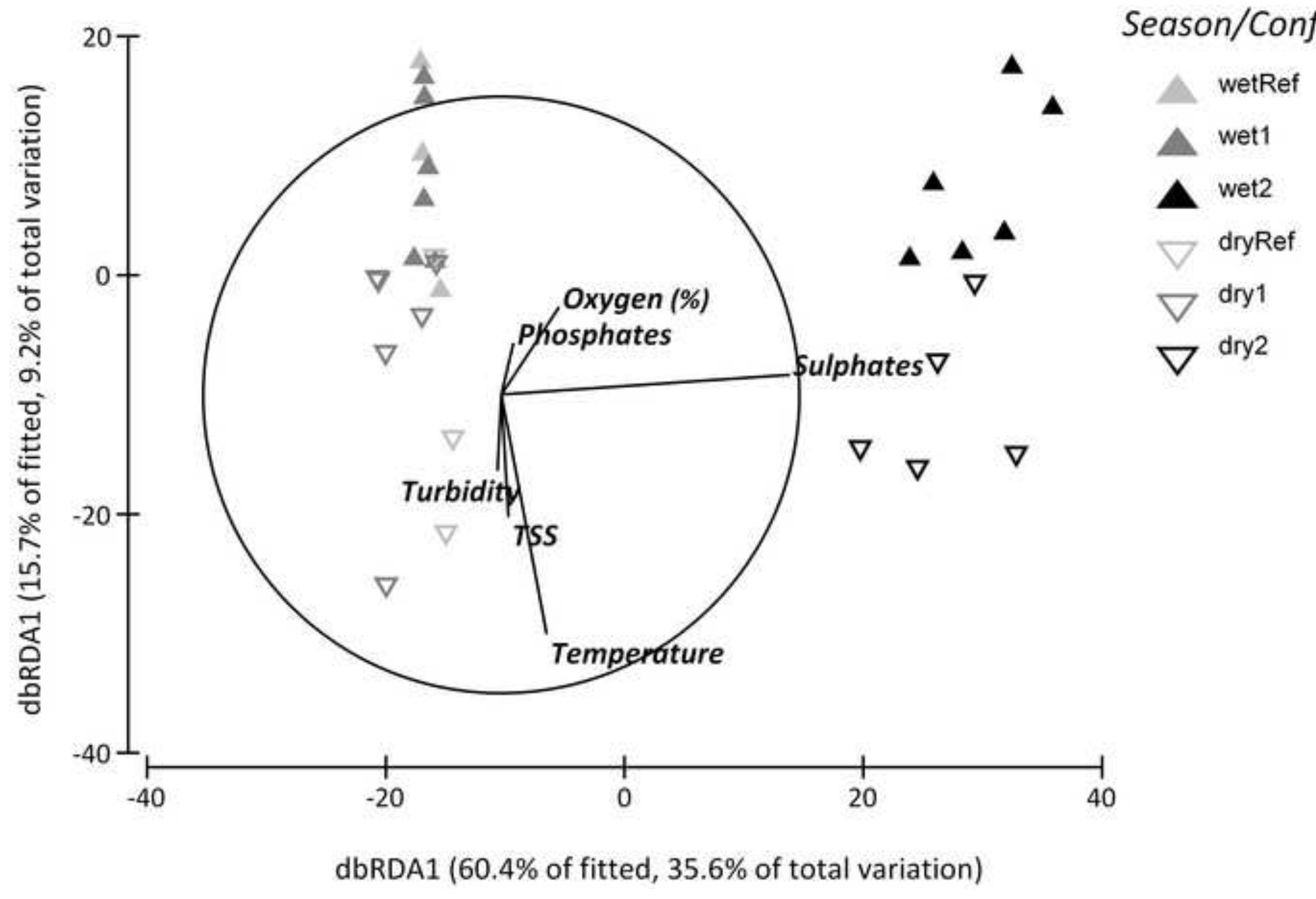

